\title{
The Academic and Social Effects of Using Social Media on University Students \\ Ünsal BEKDEMIR ${ }^{\mathrm{a}}$, Pınar TAĞRIKUULU*b
}

\begin{tabular}{l} 
Article Info \\
\hline DOI: $10.14686 /$ buefad.343249 \\
\hline Article History: \\
Received $\quad 13.10 .2017$ \\
Revised $\quad 12.01 .2018$ \\
Accepted $\quad 30.01 .2018$ \\
\hline Keywords: \\
Social media, \\
University students, \\
Academic impact \\
\hline Article Type: \\
Research Article \\
\hline
\end{tabular}

\begin{abstract}
Media tools change and transform according to the wants and needs of the society. A new concept has entered our lives as a result of these changes: social media. Popular social media tools such as Facebook, Twitter, Instagram, Wikipedia, Youtube, Whatsapp, Snapchat are used commonly, especially among young people. The effects of using social media tools are gathered under a wide range. The purpose of this study is to show the academic and social effects of using social media on university students. Within this context, interviews were made with 12 students studying at Ondokuz Mayis University, Faculty of Education during the fall semester of 2016-2017 Academic year, and the data obtained were assessed with descriptive analysis. Maximum variation sampling method was used in sample selection. The data obtained from the interviews show that using social media causes important effects on students.
\end{abstract}

\section{Sosyal Medya Kullanımının Üniversite Öğrencileri Üzerindeki Akademik ve Sosyal Etkileri}

\begin{tabular}{|c|c|}
\hline \multicolumn{2}{|c|}{ Makale Bilgisi } \\
\hline \multicolumn{2}{|c|}{ DOI: 10.14686/buefad.343249 } \\
\hline \multicolumn{2}{|c|}{ Makale Geçmisisi: } \\
\hline Geliş & 13.10 .2017 \\
\hline Düzeltme & 12.01 .2018 \\
\hline Kabul & 30.01 .2018 \\
\hline \multicolumn{2}{|c|}{$\begin{array}{l}\text { Anahtar Kelimeler: } \\
\text { Sosyal medya, } \\
\text { Üniversite öğrencileri, } \\
\text { Akademik etki, }\end{array}$} \\
\hline $\begin{array}{l}\text { Makale Tü } \\
\text { Araştırma }\end{array}$ & $\begin{array}{l}\ddot{u}: \\
\text { Iakalesi }\end{array}$ \\
\hline
\end{tabular}

$\ddot{O} \mathbf{z}$

Medya araçları, toplumun istek ve ihtiyaçlarına göre bir değişim ve dönüşüm geçirmektedir. Bu değişimler neticesinde hayatımıza yeni bir kavram girmiştir: Sosyal Medya. Facebook, Twitter, Instagram, Wikipedia, Youtube, Whatsapp, Snapchat gibi popüler sosyal medya araçları, özellikle gençler arasında yaygın olarak kullanılmaktadır. Sosyal medya araçlarının kullanımından kaynaklanan etkiler ise oldukça geniş bir yelpazede toplanmış durumdadır. Bu çalışmada sosyal medya kullanımının üniversite öğrencileri üzerindeki akademik ve sosyal etkilerini ortaya koymak amaçlanmıştır. Bu kapsamda 2016-2017 yılı güz döneminde Ondokuz Mayıs Üniversitesi Eğitim Fakültesi’nde öğrenim görmekte olan 12 öğrenci ile görüşmeler yapılmış; elde edilen veriler betimsel analiz yoluyla değerlendirilmiştir. Örneklem seçiminde maksimum çeşitlilik örnekleme yöntemi kullanılmıştır. Görüşmelerden elde edilen veriler, sosyal medya kullanımının öğrenciler üzerinde önemli etkiler ortaya çıkardığını göstermektedir.

\footnotetext{
*Corresponding Author: pinar.tagrikulu@ omu.edu.tr

${ }^{\text {a }}$ Prof. Dr., Giresun University, https://orcid.org/0000-0002-7767-9088

${ }^{\mathrm{b}}$ Res. Asst., Ondokuz May1s University, https://orcid.org/0000-0002-5221-6888
} 


\section{Introduction}

Media evokes a great number of things. It is possible to call "media" all of the contents ranging from the brand of the watch on our arm, to the symbols on our clothes, to a poster we see on a board, a show we watch on TV, or a song we listen to on the radio. The reason why media has such a wide place in the social sphere today results from new developments in communication and information technologies (Karagöz, 2013). As the significance of the place media has in the social sphere is understood, it is thought that it is not very easy to stay away from the media and to lead a life isolated from the media.

Media has caused such strong effects on our lives through media tools. These media tools have undergone great changes from the early times they have appeared to our day. Changes that have occurred in time in individuals' lives, wishes and needs have also begun to change the content of media tools and these tools have undergone a change and transformation in them. While a great number of media tools such as telephone, television, computer and radio experienced this change within themselves, internet underwent the greatest change and transformation. The changes and transformations that occurred in internet gained speed with the changes in the expectations of society. The uses of the internet which serve many purposes such as the circulation of knowledge, sending and receiving e mail, shopping, education and communication must have become insufficient for individuals in time that needs such as using different channels in mass communication have begun to emerge. These needs have occurred in many different dimensions and people's wishes for others to see and like the details in their lives and at the same time their wishes to know about those people's lives have brought a new concept into our lives: social media. Social media has become a determinant in varying, popularizing, shaping, internalizing, sharing and reaching information. Individuals can now reach a great number of information they want through social media while they can also follow the agenda closely and become the source and commentator of news as its subject (Babacan, Haşlak \& Hira, 2011; Kamiloğlu \& Uluğ Yurttaş, 2014).

While social media presents a virtual communication medium (Yegen, 2013), it also expresses a concept which introduces all of the dimensions of user and technology in an integrative way (İşlek, 2012). With this aspect, social media is the name given to social platforms in which users share their information, experience and interests through internet or mobile systems (Sü Eröz \& Doğdubay, 2012). Social media is a new online media group which enables sharing within the context of participation, openness, chatting, society and being connected and social media forms are basically shaped in six dimensions. These are: social Networks (MySpace, Facebook, Bebo etc.), blogs, wikis (wikipedia etc.), podcasts (Apple, Itunes etc.), forums, content groups (Flickr, Youtube, del.icio.us etc.) and micro blogs (Twitter etc.) (Mayfield, 2008, p. 5-6). Social media, which shows a structure that puts the individual in the centre has increased its number of users each day and has reached hundreds of millions users (Çildan, Ertemiz, Küçük, Tumuçin \& Albayrak, 2012). Social media applications which owe their functioning to internet technology provide a wide dialogue environment to their users (Yağmurlu, 2011). In this dialogue environment, individuals catch the opportunity to share their ideas and opinions with users they interact (Toksarı, Mürütsoy \& Bayraktar, 2014). With the decrease in individuals' orientation to traditional communication tools, social media applications cause important effects on these individuals' social and cultural lives (Barutçu \& Tomaş, 2013). Social media removes geographical, physical and economic obstacles and enables individuals to enter groups in which they cannot possibly enter in real life and enables individuals to express themselves more easily (Kakırman Y1ldiz, 2012).

Besides benefits resulting from personal use, social media tools make great contributions to institutions' functioning, accelerating the marketing activities of brands and products and reaching wider masses (Onat \& Aşman Alikılıç, 2008). Today, businesses have realized this benefit and tended to make their marketing and promoting strategies through social media (Haciefendioğlu, 2010).

Social media is one of the most ideal media since it has a structure which can continually be updated, it is open to multithreading and it allows virtual sharing. People can share their thoughts and discuss these thoughts in social media and thus, new ideas can emerge. In addition, through social media people can share photos and videos in addition to personal information, they can look for and find jobs and real life can be experienced in virtual media. The fact that social media has these powers attracts the attention to this field as time passes by and a new conceptual framework is formed for renewed virtual world (Akınc1 Vural \& Bat, 2010). Increases in the use of mobile devices such as smart phones, tablets; increasing internet penetration in all countries of the world and fast circulation of information also increase these powers of social media day by day (İşlek, 2012). The increase in the number of users increases the power of media, and it becomes very easy to share information and create content in the social 
media (Çildan et al, 2012). In addition to its advantages in many areas, social web technologies, which have important advantages in the field of education, have advantages in making education processes active, creative and supported by cooperative learning, increasing student-student, student-lesson content and teacher-student interaction, making students work their skills such as researching, questioning and problem solving (Gülbahar, Kalelioğlu \& Madran, 2010). Other advantages of social media tools for people are being fast, contemporary, inexpensive and reliable, allowing bidirectional relationship, enabling information production while at the same time allowing for information consumption, giving individuals the opportunity to choose and give quick answers (Öztürk \& Talas, 2015). The academic effects of social media tools on students are shaped in line with the intended purposes of social media tools. However, in case of using social media tools only for purposes of having fun, spending time and playing games, its positive effects cannot be mentioned in academic terms to a great extent. However, in cases when websites related with education and scientific publications are followed, it can be stated that using social media can possibly have academically positive reflections. Students need to be motivated and stimulated for this. As a result of this motivation, it can be possible to form groups which enable sharing academic content, providing participation in these groups and sharing content (Akbaba, 2006).

Social media tools which have lots of advantages do not always provide advantages to individuals; instead sometimes they can cause undesired results. Problems can occur in return of negative results which are caused by unconscious use of social media tools. Especially the problems which occur as a result of unconscious use of social media by children and young people can later cause these people to experience problems. Cyber bullying, which occurred as a result of internet and cell phone use becoming wider among students, building negative relationships in social media and internet addiction are examples of these problems and these problems cause important psychological pressures on students (Özdemir \& Akar, 2011).

Internet addiction is one of the most probable problems which are thought to imply social media use. Internet addiction presents itself with a gradually increasing time, money and energy allocated to internet activities, and it can reach dimensions which are too dangerous to make sufferers experience undesired feeling such as anxiety, depression, emptiness and loneliness when sufferers are not online (Kandell, 1998, p. 12). There can even be cases of consecutive failures in stopping, controlling or cutting down internet use in individuals with internet addiction and cases of endangering some relationships in business life or social life (Young, 1998, p. 238). Another problem is delaying responsibilities that should be fulfilled in real life as a result of internet and social media addiction. Delaying these responsibilities causes accumulation of the works that should be done later and also time loss (İşman \& Albayrak, 2014).

The facts that social media is everywhere and easily accessible, operators encourage people to speak and text and internet is accessible on smart phones have caused communication to become a man-made, artificial need rather than a humane and essential need (Göker, 2015). However, despite all this convenience in social media platforms and telecommunication, it can be seen that there is an increase in communication problems instead of a decrease. It is a known fact that lack of communication, not being able to communicate sufficiently with people around, lack of sincerity and friendship in relationships cause a feeling of loneliness and this in turn causes individuals to be unhappy and to experience important problems in characteristics (Yüksel Şahin, 1998). Based on the fact that many people an individual interacts with since birth have an influence on the individual's character, mental health, attitudes and behaviours, it can be stated that problems in interpersonal relationships can deeply influence individuals and these problems can become fundamental problems in an individual's life (Nacar \&Tümkaya, 2011). Today, the increase in virtual communication decreases time allocated to real life and children and young people cannot communicate face to face with people who can have an influence on their development. This in turn makes children and young people become lonelier and more introvert gradually (Kakırman Yildiz, 2012). However, today individuals need to have more command on communication skills, and especially individuals such as psychologists, physicians, nurses, teachers, social services experts, lawyers and sales people who have to be together with people more than other occupations need to be more equipped with these skills. When it is considered that children and young people are candidates of these occupations in the future, it can be understood how important communication skills are for them and social media use which influences this should be in a balance with real life because when the time allocated for social media use is not balanced with the time allocated to real life, it can be seen that communication does not get easier, but instead becomes more difficult (Korkut, 2005). 
As can be seen, with developing technology, social media has taken an important place in teaching environments and interpersonal relationships. Internet technologies which have changed the content of teaching environment have brought together the need for educational institutions and people to keep up with the age. With web-based technologies entering individuals' lives, communication and interaction have become easier, and it has become possible for individuals to communicate as a part of these webs. As a result of developments, changes have been observed in technologies used in meeting individuals' needs for education and also in these needs. In addition, these technologies have changed the structure of education system and caused changes in learning and teaching activities. Like media, education also got rid of its traditional structure, changed its form and it gained an informal and social learning focused structure giving up its school and class based formal structure (Ekici \& K1yıc1, 2012).

The purpose of this study is to show to what extent university students' reaching information, sharing academic information and classroom interactions are influenced by social media use. For this purpose, interviews were made with the students in the study group. Based on the interviews, answers were sought to find out whether social media use is effective on students' reaching information, sharing academic information and classroom interactions and if it is, to show what kind of effects these effects are. Within the context of the study, answers were sought to the following questions:

1. What do students think about social media in general?

2. How are the positive/negative effects of social media use shaped on students' reaching information and sharing academic information?

3. How are the positive/negative effects of social media use shaped on students' classroom interactions?

\section{Method}

\section{Study Group}

The study group consists of 12 students studying at Ondokuz May1s University Faculty of Education during the academic year 2016-2017. In forming the study group, students' academic achievement averages were taken into consideration and maximum variation sampling method was used. Within this scope, most successful 4 students, average level 4 students and least successful 4 students were chosen from a class consisting of 60 students on average. Students who did not attend school were not included in the study group. Interviews were made with all the students in the study group.

Table 1. Characteristics of students who participated in the study

\begin{tabular}{cccc}
\hline Student's Code & Gender & Age & $\begin{array}{c}\text { Rank in academic } \\
\text { achievement }\end{array}$ \\
\hline S1 & Female & 20 & 1 \\
S2 & Female & 21 & 2 \\
S3 & Female & 20 & 3 \\
S4 & Female & 22 & 4 \\
S5 & Female & 20 & 26 \\
S6 & Male & 20 & 27 \\
S7 & Male & 21 & 28 \\
S8 & Male & 22 & 29 \\
S9 & Male & 20 & 54 \\
S10 & Male & 21 & 55 \\
S11 & Female & 23 & 56 \\
S12 & Male & 20 & 57 \\
\hline
\end{tabular}

\section{Data Collection Tool}

In this study, interview method was used and the interview form developed in the light of literature was used as data collection tool. This form was finalized with the required corrections after experts' views were taken and pre-interview was made with a student outside the sample group. 
Some additional methods (variation, participant confirmation, colleague confirmation, etc.) are needed for the researched phenomenon and event to have an integrated structure (Yıldırım \&Şimşek, 2013, p. 290). Using these methods is important for the reliability and validity of the study. Validity expresses measurement tool's measuring the subject free of error (Aziz, 2010, p. 59), significance of the findings of the study, persuasiveness, authenticity and generalizability of the study (Miles \& Huberman, 1994/2015, p. 278-279). Reliability is approached in a different way in qualitative researches when compared with quantitative researches. Here, acting meticulously in each state starting from the processes before beginning the research, the research process, and the process of analyzing the data is very important in terms of ensuring the reliability of the study because it is accepted from the start that in qualitative researches, the truth can change from person to person and from environment to environment and the same results may not be reached all the time when the research is conducted with similar groups (Yıldırım \& Şimşek, 2013). Thus, in qualitative studies, reliability is a concept which can be predicted with whether everything in every stage of the study is discussed with a reasonable care (Miles \& Huberman, 1994/2015, p. 278). In this study, for reliability and validity, first of all pre-interview was made with a student outside the research group and the comprehensibility of the questions was tested. This interview was not included in 12 interviews conducted with the study group. With the edits after this interview, the interview form was finalized. Following this, the data obtained from the interviews with 12 students in the research group were analyzed and the study was finalized by presenting the interpretations to another researcher.

\section{Data Collection and Analysis}

The study was conducted with 12 students studying at Ondokuz Mayis University Faculty of Education during the academic year 2016-2017. All of the students chosen as sample participated in the interview. The interviews were recorded with permission from the participants. The data obtained were analyzed with descriptive analysis. The data obtained with descriptive analysis can be organized according to predetermined themes or they can be presented in line with the questions and dimensions used in the interview or observation process. The opinions of the interviewed individuals are frequently given as direct quotations. The data obtained are described systematically and obviously and these descriptions are explained and commented, cause and effect relationships are presented and conclusions are reached (Yıldırım \& Şimşek, 2013, p. 256). In this study, the data organized according to pre-determined themes were assessed with descriptive analysis. Each student was given a code to analyze the data obtained. The students were coded as S1, S2, S3...S12 from the first student to the last one.

\section{Results}

In this part of the study, the views of students interviewed were taken about social media and the effects of social media on students' reaching information, sharing information and their classroom interactions were assessed.

\section{What the concept of social media evokes in students}

In this part of the study, what the concept of social media evokes in students was researched. For this purpose, the students were asked the question "What comes to your mind when you hear the word social media?". When the answers were analyzed, it was found that when they heard the word social media, what came to students' minds was social media tools such as Facebook, Instagram, Twitter, Swarm, Whatsapp, Tumblr, Snapchat and Youtube, which are popular social media tools of our day. The students' expressions about this question are as follows:

S1: When I hear the word social media tools, computer, telephone,... that is, all kinds of mass communication tools where the internet can access come to my mind.

S2: Facebook, which I generally use, [comes to my mind].

S3: When I hear the word social media tools, tools such as Facebook, Twitter and then Youtube come to my mind.

S4: Facebook, Instagram, Twitter and Whatsapp.

S5: Facebook comes to my mind first. Later, Twitter, then Instagram, Tumblr and Snapchat come to my mind.

S6: Facebook, Instagram, Whatsapp, Twitter, Snapchat and Swarm come to my mind. 
S7: Online games, Instagram [I am generally interested in these] come to my mind as social media tools. As for online games, I always play chess. I play with foreigners, too. I can interact with them. I follow players who are better than me. Instagram and chess are the most important for me. I don't look at Facebook because as we can see today, Facebook is in a very bad condition.

S8: Social media is something we are continually addicted to Instagram, Facebook, Whatsapp, Twitter come to my mind.

S9: Facebook, Instagram, Twitter and Whatsapp come to my mind.

S10: Facebook, Twitter, Swarm and Instagram come to my mind.

\section{Social media tools used by students}

This part of the study answers the question of which social media tools students use. It can be seen that students actively use social media tools such as Instagram, Youtube, Facebook, Swarm, Online Chess, Twitter, Messenger and Whatsapp. No significant difference is seen between the students' academic achievement ranks and the social media tools they use; however, a variety is seen in social media tools as the level of academic achievement decreases. It can be seen that while students with high level of academic achievement use at least 1 at most 3 social media accounts, students with low level of academic achievement use at least 3 at most 5 social media accounts. This result brings to mind that the variation in the social media tools used can be inversely proportional to academic achievement. One of the students expressed being almost at the level of addiction in using social media tools and stated that not only him but also his friends were like this. This student, who emphasized that where students stayed (dormitory) was also effective on this result, stated that students sometimes accessed social media accounts even in lessons. The students' expressions are as follows:

S1: Yes, I use social media tools like Instagram, Youtube. Even if I do not have my own account, I use tools such as Facebook from my brother's account.

S2: I generally use Facebook and Whatsapp.

S3: Yes, I use some. For example, Youtube.

S4: I use Facebook, Instagram and Whatsapp.

S5: I use only Facebook and Instagram.

S6: I use some of these, if not all. I use Facebook, Instagram and Whatsapp'.

S7: Instagram, Online chess, and rarely Facebook.

S8: I used to use Facebook. I recently closed my account. I use Instagram and Whatsapp. I have been using social media for a long time. However, it seems like I've been spending little time gradually. I think that where we stay has a great influence. I am staying in a dormitory. Especially this influences a lot. I think that people around me are also addicted. I see them all the time, too. We are six people in the same room. As a result of my observations, I can say that everyone is addicted to the internet. I am, too. We access the internet even in the lesson, although we shouldn't.

S9: I have Instagram, Facebook and Whatsapp accounts, but I access them rarely. I check Facebook once in two weeks and Instagram maybe once a day, to see what people have done. However, I spend a lot of time for computer games.

S10: I do. I use Facebook. Twitter, Instagram and Google Plus. Nothing else.

S11: I use most. I use Whatsapp, Facebook, Messenger, Swarm and Instagram.

S12: Of course, I use most. I have a Facebook account since I've been very young. I also use Twitter and Youtube actively. I don't use Instagram too much. 


\section{Time allocated to social media tools}

This part of the study examines how much time a day students allocate to their social media accounts. It was found that students allocated at least 10 minutes or at most 15 hours a day. While it was found that students with high academic achievement allocated 1-2 hours a day to social media tools, one of these students was found to differ from other students with a social media use of 15 hours a day. Students with average levels of academic achievement were found to allocate 1 to 5 hours a day to social media. Students with low levels of academic achievement were found to allocate at least 3 and at most 10 hours a day to social media. One of these students was found to allocate 10-15 minutes a day to social media. Although there are such examples, it can be seen that as the time allocated to social media increases, average academic achievement decreases. On the other hand, there are situations in which a student who allocates 15 hours a day to social media has high academic achievement, while a student who allocates 10-15 minutes a day has low academic achievement. However, these situations are assessed as low frequency and they are not allowed to cause generalization on the group. Students' expressions about the time they allocate to social media use are as follows:

S1: Not too much, since I generally study, I allocate 1 or 2 hours a day on social media to spend my time.

S2: Depends on the day. However, I allocate less time when I'm home. I spend 2 hours at most here.

S3: I allocate 1-2 hours a day, I guess. It's not that much.

S4: I can't calculate. I have the phone in my hand all the time. I just put the phone away from myself when I'm studying. I spend 15 hours a day.

S5: Depends on the period. I spend too much time in midterm weeks. However, I am not very much interested normally. 1-2 hours a day at most.

S6: I allocate too much time. I don't use much when I'm at school. For example, if the lesson starts at 17:15, I try not to look during this time. However, I'm staying in a dormitory. I spend my time in social media when I'm in dormitory. This makes 4-5 hours a day on average.

S7: Let's think of chess separately because there is a purpose of developing mind there. Since my purpose is to advance in the field, I spend about 2-3 hours. I spend 1 or 2 hours in Instagram. I spend a total of 5 hours a day on the internet, but 3 hours of this time is useful.

S8: I access my social media accounts frequently but for short amounts of time. I mean, I spend at least one and a half to two hours a day.

S9: Very little. 10-15 minutes a day.

S10: How much time do I spend a day... My computer is on all the time when I'm home. I play some games and it is open all the time at the background. This time changes each day. It's about how much time I have when I get home from school... I can say for eight hours.

S11: Almost half of my day. I allocate 8-10 hours.

S12: In fact, it depends on what I'll do that day. Some days it can be 3-4 hours if I don't have anything to do; however, if it is a busy day, it is enough to check only 15-20 minutes from the phone. I can control myself about how much time I'll allocate to social media.

\section{Purposes for using social media}

Purposes for using social media are different and varied. For example, while Instagram is used for sharing photos or videos and messaging, Facebook has more uses. Here, in addition to sharing photos, videos and messaging, people can form groups and make shares for the purposes of these groups coming together. Youtube is a platform which serves millions of people a day by allowing people to share videos. Here, people can create their channels and get the opportunity to make masses hear their voices. Whatsapp is used for messaging to a great extent and by forming groups, it allows people in these groups to chat with each other as if they are in the same environment. However, it can also be seen that opportunities such as communication, fun, shopping and education are also reached through these platforms. 
It was found that the students in the study group used social media tools in general for purposes such as having fun, communicating, following people, pages and news, academic studies, for boredom and for watching films. It was found that while students with high level of academic achievement used their social media accounts for fun, communication, following people, getting notes for lessons, self-improvement and watching videos to contribute to them academically, students with low level of academic achievement used their social media accounts for fun, communication, for boredom, watching film, studying, following people and pages and academic studies. Based on students' expressions, it can be seen that students with high level of academic achievement used social media tools in a way that they contribute to their academic achievement or in a way that won't interfere with their academic achievement, while students with low level of academic achievement were not anxious about this issue in general. The students' expressions are as follows:

S1: In general, I have a busy schedule at school. Since I study all the time, I use social media tools to distract my mind. I use them for fun. For example, cooking is my hobby and I generally spend time on pages with recipes or pages on clothing.

S2: I generally use Whatsapp to talk to my friends and to see who does what with whom. During the exam week, I look at subjects sent by my friends. I compile my notes from here.

S3: I use social media tools sometimes for education and sometimes for fun, depending on ways that differ with how busy my day is. If it is school time, I generally use it for education. For example, there is Youtube, it is not on the forefront when compared with others. People upload videos, open channels for themselves and share various things from here. They even share their own life sometimes. I follow them. Sometimes some academics or some teachers have special channels for them and teach there. I watch these. Except these, sometimes there are foreign Youtubers. I see their life styles and the geography of their countries more easily. However, if I'm not outside the school, I use social media to have fun and to develop myself in terms of culture.

S4: Ifollow the news more on Facebook. Especially, I follow news about Samsun. I follow my friends on Instagram. Whatsapp is all the communication tool we have now. There is no such thing as sms.

S5: I use it to get information and to be able to talk with people I know who are away. I am also questioning this right now. What is my purpose in using social media?....

S6: I can say that having fun is my priority because I follow comedy pages. I use it for educational purposes also. For example, I follow KPSS pages.

S7: I use them for fun and to follow the news. I use chess for information.

S8: [I use them] to follow someone and to see my friends. I use Instagram. I am there all the time. I don't have a specific purpose. I just want to have fun. This is a bit addiction. I don't see any use, either. I think that Whatsapp is a bit useful.

S9: I generally check the news. I try to know about what's happening in the world. I try to learn where my friends went and what they did there.

S10: I use social media to dispel my boredom. It depends. I do not have a specific purpose exactly. I look at whatever there is on the main screen. I mean, I don't use social media for a special purpose.

S11: I use social media to see what my friends have done that day, or just to spend time, watch films and to be informed about some subjects. I use it to check the meaning of a word I do not understand while I'm studying, to reach notes.

S12: I use social media to have fun and spend time. I follow my team on Twitter. I follow a few news pages. I do not aim to follow someone. I use Facebook for ordinary purposes, to spend time. 


\section{Effects of Social Media use on reaching information and sharing academic information}

The students were asked whether their social media use was effective on their reaching information and sharing academic information, and if their answer was yes, they were asked to explain how this effect occurred. The students who stated that social media use had positive effects on reaching information and sharing academic information showed a great number of proofs for this. The proofs shown for positive effects are enabling people to stay away from stress, positive effects on motivation, easing students' minds by contributing to spending free time, giving the opportunity to learn information about history, geography and subjects of public personnel selection examination (KPSS), providing professional and academic information and making it possible to share notes on lessons. In addition, enabling students to know about cultures and countries through instructive videos, easy access to sources of information and sharing information are useful situations of social media use to students. Students also emphasized the significance of Whatsapp application about sharing notes and questions. The students' expressions are as follows:

S1: I don' think that I am directly influenced academically; however, it helps me to be motivated. It helps me to get away from stressful situations. Thus, I think that it helps me in terms of motivation. For me, using social media is something like a relaxation tool. It helps me to concentrate on other things rather than studying all the time. When I sit down to study later, it helps me to be more concentrated. For me, it is something like a way to have fun, to spend time. It enables me to get information on my own profession, geography, history and KPSS. It allows me to see comments about fields such as being a civil servant. Most simply, I can learn the comments of people in the field. In this sense, it has an extra use for me to get new information about the future and to be motivated. However, it is not a very big variable for me except these.

S2: It is good for me that my friends share their own notes from Facebook or Whatsapp. I look at what is missing in my notes, what they've written different, what their comments are. Thus, it is useful for me.

S3: My department has an interaction with geography and different Youtubers have videos they shoot about their countries. When I watch these videos, I learn information about these countries even without realizing. Thus, I learn about their culture and interact without going there. Sometimes I can make up for the things I lack by watching instructive videos. The advantages are these for me. If we take a look at its disadvantages, for example you start with one or a few videos first, if you can't stop yourself, you can watch different videos for hours. It depends on your will. You waste your hours watching videos because they are very colourful. This causes loss of time. However, it does not prevent me from studying much because I make daily programs. Before my studying hour, I complete during an hour whatever what I'm curious about so that I don't interrupt studying saying I wish I had looked at that. I look at whatever I'm curious about. Then I sit down to start the lesson and I completely concentrate on the lesson. Social media use generally has a positive effect on me.

S4: When I wonder about something, I directly check from the internet instead of searching from books because it does not last a second. I spend lots of time while looking for something. We share notes all the time through Whatsapp.

S5: We share questions. For example, recently I had Class Management lesson. There were questions shared on Facebook for Open University exams. I answered these questions and they were useful for me, too.

S6: For example, the class has a Whatsapp group and friends send notes from there. I follow pages on education. Social media is useful that way.

S8: I use for exchanging notes. We take the photos of notes. My friends send and I get them. Thus, it is positive.

S9: I can say that history pages I follow on Facebook have a positive effect. A few things I heard there have a positive effect.

S11: I can learn many things I don't know from there [social media]. I can get help from people who have information about their field. There are some groups on KPSS questions about Social 
Sciences on Facebook or some groups about Social Sciences Teaching. Our class has a group. Questions are shared here. These are useful for me. I exchange notes with friends I feel close on Whatsapp. These have academically positive influences on me.

S12: I follow some pages like history, KPSS questions. I use Instragram for that purpose more. However, I don't believe that Facebook has such a contribution. However, as I said, I have 6 failed courses from my second year. The reason for these lessons is not social media use.

Students' social media use does not always cause positive effects on their reaching information and sharing academic information. Students showed a great many evidence for the negative effects of social media use. These are negative effects on lessons, poor concentration, delays in studying, loss of time, and poor motivation. Other negative aspects of social media are a talk for academic studies on social media turning into a talk for fun, loss of time brought about by the wish to spend more time, unnecessary bulks of information filling in students' minds and its harms on health. The students' expressions are as follows:

S1: In general when I look at something that attracts my attention, this becomes a disadvantage for me in terms of motivation if I have to study afterwards. Being wrapped up in that, the wish to spend more time...This sometimes has a negative effect on adaptation. .

S2: Sometimes, when talks are too long, we leave the lesson and start talking about something else. Starting with the friends with the purpose of studying and then beginning to chat for fun is bad for me. I want the internet to go off then, but I don't want to upset my friend. I continue to talk but I feel very uncomfortable. This waste of time influences me negatively.

S3: If I start when I give a break to studying, the break which starts as 15 minutes continues up to 1 hour.

S4: I lose too much time. This affects me negatively. We cannot direct it, but it directs us. I lose most of my time there. I can even be stuck with nonsense things for hours. However, I can make use of that hour better.

S5: When I get the phone and say "let me look for two minutes", I end up with spending hours. It has negative effects such as loss of tine, filling my brain with unnecessary information and it also has negative effects on my health. It is harmful for my eyes. It also has negative effects on my lessons.

S6: For example, I sit down to study. When my concentration gets poorer, I want to look at my cell phone immediately. I cannot help but think about it and I cannot study.

S8: It affects my studies. Most of the time I say I will study soon. Let me surf the net a bit more, play a bit more. And I am influenced more negatively. I spend my time. I cannot study. It is generally negative. I am aware of how serious this is. I use it a lot. I also say that I have to give up but I can't. Even if I cut down on it, I can't stand again when some time passes. I can't stop using even if I cut down on it.

S9: The games I play have a negative effect on my lessons because sometimes I get notes from my friends thinking that I will study. I put my papers out to study but I get bored after some time. I play games. Maybe if I won't play games, I will force myself a bit even if I get bored. However, when there is a more fun option, I prefer to play games instead of studying.

S11: I can spend my time on lots of unnecessary things. I spend most of my time there. I lose too much time.

There were also students who stated that their social media use had no effect on their reaching information and sharing academic information. While one of these students stated that he used social media as a tool to make use of his free time, two students stated that their social media use had no effect on their reaching information and sharing academic information. These two students were students with low academic achievement. The students' expressions are as follows:

S7: Maybe chess has an effect but Instagram does not have any effects at all. I'm staying in a dormitory, thus I have lots of free time. I use social media to make use of this free time. 
S10: My social media use does not have any positive or negative effects on me. I won't use it if I say that I won't. For example, my phone is broken and it doesn't mean anything to me right now. I mean, it is not an addiction for me. In fact I wanted to study psychology at university. Therefore, I studied a lot. But I couldn't get a place; instead I got a place at this department. However, I don't want to be a teacher. For example, I can have my own business and study psychology at a private university. I will be a teacher if I can't do any of these. My academic achievement in the department is caused completely by the fact that I don't want to study.

S12: My achievement is not related with my social media use. The lessons I failed are from last year. I had difficult times then. I had some personal problems. Thus, I am not influenced by social media academically.

\section{The effects of social media use on classroom relationships}

University period is one of the most important times when individuals leave their families and start standing on their own feet. While students try to adapt to a new city and life within this period of time, their new friendships are also influential in this period of adaptation. While this process is easy for some, it is difficult and complicated for others. This is caused by many factors. Since some students are more outgoing and social, they are more successful in making new friends and more successful in maintaining these friendships, while others cannot maintain this process in the same way.

In this part of the study, answers are sought for the question of whether students' social media use are effective on their classroom relationships, if they are, to what extent this effect is. While some students stated that their social media use had positive effects on their classroom relationships, others stated that it had negative effects. The students who stated that social media use had a positive effect on their classroom relationships stated that through social media, they could communicate with people they did not communicate with in daily life. These students also expressed that this situation had a positive impact on their everyday life relationships. There are students who stated that social media had positive effects on breaking prejudices about people, making organizations, providing a bond in the classroom, and easing face to face communication. Students' expressions are as follows:

S1: For example, although I don't speak to some people at all, I can have ideas about them. Like that person does that, this person does this... Although we have not met in person, I can have information about them through the internet. This influences my social relations positively.

S2: My prejudices disappear when I see someone who does not speak to me at all in the classroom chats with me on Whatsapp. I see that someone quiet is in fact witty. I say that I've known him wrong. I think that I can be friends with him. It influences me more positively.

S4: When we first came to class, no one spoke to each other. However, we began to talk through the internet. We started to chat only that way, otherwise no one even looked at the faces of others. It was easier to talk and to become friends through the internet. For example, I met my two very close friends on the internet before I even came to school. We became close that way. We are still friends.

S5: I talk to people that I don't in normal life and share notes with them. It has such a use. There are groups on some lessons. We talk from there. We realize the communication that doesn't exist in real life. In fact, this is the only positive effect.

S6: The positive effect is, for example I can be friends with people I can't talk face to face in the classroom through social media. I can follow them. I can communicate more easily.

S8: For example, we talked through social media and organized a picnic. This way, it had a positive effect on our bonding. I can say that this is the only benefit of it for class.

S11: Most of the time, people are ashamed of each other in the classroom and they don't communicate with each other. However, we get in touch more sincerely thinking that we do not see those people in person. 
S12: For example, I can communicate more easily during the day with a friend I chat with on Whatsapp in the evening because I can guess what he can react to. I don't text someone I don't feel close to. Social media influences my classroom relationships positively.

There are also students who stated that social media use influenced their classroom relationships negatively. These students stated that social media use caused them to have prejudices and made it difficult to communicate face to face and discussions could break out on social media platforms about politics and football. Students' expressions are as follows:

S1: Sometimes it causes me to have prejudices because I have ideas about people I don't know at all only through mass media communication tools. I have a profile about the person and I approach them with these ideas and this can influence my classroom relationships negatively.

S4: Sometimes unnecessary subjects are discussed. There are unnecessary discussions about politics or football. People just say whatever comes to their mind. They speak without thinking. Maybe they can tell the things they can't face to face when they are on social media. I haven't experienced such a thing, but people around me do.

S5: In fact, social media use has more negative effects in terms of communication because we don't share anything when we come together. Everyone has a phone and everyone looks at it. There is no communication. It influences communication first. Lack of communication is the most important negative effect.

S6: It leads to laziness. Communicating through the phone becomes a priority instead of face to face communication. Because of this, sometimes people cannot build sincere relationships. I think that we should use social media in a balanced way.

S7: It completely influences negatively. For example, during breaks, everyone plays with their phone. I generally talk on the phone. Everyone texts. People text during the lesson, too. If it weren't for Whatsapp, maybe more people would be better. I mean, social media is negative in every aspect.

S11: People behave closer to each other [in social media], but there is no such face-to-face interaction in our class. Sometimes things we share on social media can be misunderstood. People can misunderstand these and start discussions. That discussion gets bigger and creates problems among people. Actually, there is not good interaction in our class.

There were also students who stated that social media use did not influence their classroom relationships at all. The expressions of these students are as follows:

S3: Social media use does not have any influence on my classroom relationships because there is no one I know from school there. Thus, I don't have much interaction because the social media platform I use is not on interacting with people, but on sharing.

S7: I don't think that it is sincere to interact with people I don't know on social media. It does not have an effect on me. However, it has uses in terms of contributing to my lessons and homework. I ask for notes from my friends. I write to them on Whatsapp. I say "can I get your notes", but this interaction is built on interests. It does not have a very big effect on my classroom relationships.

S9: No, it does not influence. Since social media barely exists in my life, it does not have any effectsgood or bad. The games I play do not have any effect on my classroom interactions, but this causes me harm.

S10: I can say that it does not have any effect. The class has a Whatsapp group, but I'm not in this group.

S12: For example, a discussion in social media had been brought to classroom. Problems had occurred. I also experienced a problem on Whatsapp. If we had been together at that moment, maybe we would have killed each other with that person. But it did not become so much of a problem since it was on Whatsapp. We solved the problem the next day. But I can say that social media use does not create too many problems for me. The harms of social media depend on the person. If the person 
knows how to use social media, he can have advantages of it, while he can experience disadvantages if he doesn't know how to use it. This depends entirely on the person.

\section{Discussion and Conclusion}

Today, without being faced with any limits, individuals can transmit their ideas to masses with unpredictable numbers who are one key away from them and this gives them an important power (Tuğlu, 2017). The most important factors in fast and easy communication are recent technological developments and the widespread use of the internet in the whole world. Thus, ways of communication have become varied among people. One of these ways is social media. Since the day social media has entered our lives, it has reached millions of users and shortened the distance of communication (Çildan et al., 2012). People can now shop through social media without getting up from their seats, they can communicate, conduct educational facilities, follow news and current events and exchange information. Social media, which has a place in many dimensions of social life, has significant effects in the dimensions of education and communication as well.

For example, Facebook and Twitter, which are among the most popular social media tools of our day, can be used for the purposes of sharing lesson materials (web sites including voice files, word processor, tabulation, video files, presentations, database and other kinds of materials), following daily events, news, people and groups, sharing website addresses and thoughts, learning languages and cooperating. Thus, an active, creative and cooperative learning environment can be created and students can be better motivated to lesson (Gülbahar et al., 2010).

The effects of the increases in means of communication are not seen only in educational settings. With the increase in interest in all kinds of information and communication technologies, the power of social media increases and the concept of socializing gains a new dimension (Akınc1 Vural \& Bat, 2010). So much so that, it becomes possible to communicate with people we do not know at all through social media, to become friends with them, to share information with them and to become members of groups which are not possible to become members of in real life (Kakırman Yıldız, 2012). Thus, an environment of interaction and communication becomes possible in virtual life, different from real life.

In this study, the students were asked what they came to their minds when they heard the word social media tools, whether they use social media tools- if they do, which ones they use-, how much time they allocate a day to social media tools, for what purposes they use these tools, the positive and negative effects of these tools in reaching information, sharing academic information and on their classroom interactions.

First of all, the students were asked the question "What comes to your mind when you hear the word social media?". The students stated that tools such as Facebook, Twitter, Instagram, Whatsapp, Swarm, Snapchat, Youtube and Tumblr came to their minds when they spoke of social media. However, social media tools do not consist of only these tools. There are Myspace, Bloglar, Wikiler, Flickr, Xing and many more social media tools (Göker, 2015; Mayfield, 2008, p. 6). However, the tools that come to students' minds are relatively more popular. Thus, it is natural for students to think of these tools when social media is mentioned. The students were further asked whether they used social media tools or not and if they did, which of these tools they used. It was found that all of the students used social media tools. These tools were Instagram, Youtube, Facebook, Swarm, Online Chess, Twitter, Messenger and Whatsapp. It was found that students with high academic achievement used less (1-3) social media tools, while students with low and moderate academic achievement used less (2-5) social media tools.

When the time allocated to social media tools was analyzed, an obvious difference was found between students who had high, low and moderate levels of academic achievement; however, it was also found that one student with high level of academic achievement allocated daily 15 hours to social media use, while one student with low level of academic achievement allocated daily 10-15 minutes to social media use. When a general analysis is made, although academic achievement and the time allocated to social media use seem to be inversely proportional, what is important is what people do with the time spent on social media. Thus, the students were asked for what purposes they used social media tools. It was found that the students used social media tools for the purposes of education, information exchange, fun, spending time, controlling what friends do, watching videos, organizing lesson notes and communicating. Thus, the data obtained are in line with the data obtained from Akınc1 Vural and Bat's (2010) study. 
When the answers were analyzed in terms of the dimension of reaching information and sharing academic information, it was found that students with high academic achievement used social media with purposes which could contribute to them academically. These students pointed out such purposes as organizing lesson notes, supporting self-improvement, watching videos that they could benefit from academically, while students with low academic achievement emphasized different points. This result shows that the time allocated to social media should not be considered as separate from the purposes of why it is used and reaching information and sharing academic information were affected equally from both.

The students who stated that social media had positive effects on reaching information and sharing academic information showed evidences for this. These evidences are effects such as being away from stress, motivation, a relaxed mind, getting professional information, easy access to information sources, sharing lesson notes, and watching instructive videos. It can be understood from this that students understand how they can use social media to contribute to them academically and that they are doing activities for this. This finding is in parallel with Tuğlu's (2017) results that students use social media not only to communicate, but also to reach information and to share academic information. When it is considered that social media has many more uses other than these, it can be stated that students make choices useful for themselves and thus they are conscious social media users. Despite these positive examples, there were also students who stated that social media use had negative effects on their reaching information and sharing academic information. These students stated that the wish to spend more time on social media, talks for academic purposes changing their forms, the time allocated for internet during breaks getting longer, delaying academic studies for the time allocated for internet getting longer, notices coming to phone while studying causing poor motivation had negative effects on reaching information and sharing academic information. In this regard, this result was similar to Duman's (2008) result. Students' common complaint is the fact that too much time allocated to social media makes it difficult to allocate time to studying. Despite the examples given to all these effects, there are also students who think that the time spent on social media use does not have any effect on reaching information and sharing academic information.

When the students were asked how social media influenced classroom relationships, it was found that this influence was both positive and negative. There are many evidences shown for positive effects. These are, breaking prejudices about people, the fact that it is easier to maintain the communication which starts on social media, the fact that groups on social media platforms make everyday life communication easier, classroom bonding and easiness of communicating despite the difficulty of face-to-face communication. Students' social media use provides a more effective communication environment in the classroom and facilitates the process of communication. In this sense, it can be stated that the role of social media for facilitating communication is strong. In their study, Şahin Baltacı, İşleyen \& Özdemir (2012) stated that social sharing webs are places that can be preferred by people who are anxious about communication. The point emphasized in the related studies support our findings. The students who stated that social media use had negative influences on classroom relationships stated that social media could cause having prejudices, discussions on social media could be reflected in classroom communication, sincere relationships did not exist on social media, and sincere relationships built on social media could not be built face-to-face. Some of the students stated that their social media use did not have any influence on their classroom relationships.

Today, social media has influences on many aspects of life. Education is one of the most important of these fields. Thus, it is very important to include social media on education processes (Özmen, Aküzüm, Sünkür \& Baysal, 2011). In this regard, it is an undeniable fact for educators and students to be aware of the educational potential of social media. Higher education institutions can develop strategies about the functioning of social media in education processes and they can inform the educators during the process. In this sense, educators can be given in-service training and their awareness on the issue can be increased and education and social media tools can be integrated. Educators can in turn give their students seminars about how social media can be used within the education process. Thus, both educators and students can be made to reach an awareness about social media (Kilis, Rapp \& Gülbahar, 2014).

A social media group used by both educators and students can be created and these groups can be used within the context of the lesson. This suggestion is supported by the findings in Akdur, Yetişken \& Bilici's (2013) study. This study has shown that students studying at Ankara Vocational High School thought that supporting their educational processes through social media was effective. Other findings of this study are students' becoming more effective by including them in the education process and making their learning processes easier. It will be a 
suitable approach to build the technical infrastructure allowing social webs in every stage of education and supporting teachers on this issue (Özmen et al, 2011).

Today, social media is used from people of all ages. For this reason, lessons can be taught about the conscious use of social media from pre-school to university. The time allocated to the lesson of media literacy can be increased and in one unit of this lesson, information and activities about social media can be included. However, at this point, not only students and the school, but also the families should be made to take responsibility and there should be an integrative, complementary and supportive order between home and school (Elma et al., 2009).

Social media also has a dimension which influences interpersonal relationships. Here there is an environment which allows both visual and written communication. Based on students' expressions, it can be stated that the communication environment in social media has both positive and negative effects on real life communication. The most striking example given by students about the negative effects of social media on communication is the fact that social media makes face-to-face communication more difficult. Considering that the students in the study group are prospective teachers and teachers' communication skills should be strong, it is thought that students should be helped on this issue. In this sense, studies for easing face-to-face communication can be included more in Human Relationships and Communication lessons in universities. Students can be told that they should keep their behaviours under control while using social media and that they should act by thinking that the communication built here can be reflected on the classroom interaction. Based on the result that there are students who stated that spending the hours allocated to academic studies on social media use influence the period of studying negatively, it will be useful for students to review their purposes of using social media and keep this time to a moderate level. In this sense, it is thought that it will be useful for parents of especially primary, secondary and high school education students to keep the time allocated on social media use under control. 


\section{Sosyal Medya Kullanımının Üniversite Öğrencileri Üzerindeki Akademik ve Sosyal Etkileri}

\section{Giriş}

Medya denildiğinde akla gelen pek çok şey vardır. Kolumuzdaki saatin markasından bir futbol takımının logosuna, giydiğimiz kıyafetlerin üzerinde yer alan simgelerden bir panoda gördüğümüz afişe, izlediğimiz televizyon kanalındaki diziden, radyoda dinlediğimiz bir şarkıya kadar uzanan içeriklerin tamamına "medya" demek mümkündür. Medyanın günümüzde toplumsal alanda kendine bu kadar geniş bir yer edinmesi yeni iletişim ve enformasyon teknolojilerindeki gelişmelerden kaynaklıdır (Karagöz, 2013). Medyanın toplumsal alanda kendine edindiği bu yerin önemi anlaşıldıkça medyadan uzak kalmanın ve medyadan soyutlanarak bir hayat yaşamanın da çok kolay bir durum olmadığı düşünülmektedir.

Medyanın hayatımızda böylesine güçlü etkiler yapması medya araçları sayesinde olmuştur. Bu medya araçları, ilk ortaya çıkmaya başladıkları zamanlardan günümüze büyük değişimler göstermiştir. Zaman içinde bireylerin yaşantılarında, istek ve ihtiyaçlarında meydana gelen değişmeler, medya araçlarının içeriklerini de değiştirmeye başlamış, bu araçlar kendi içlerinde bir değişim ve dönüşüm geçirmişlerdir. Telefon, televizyon, bilgisayar ve radyo gibi pek çok medya aracı kendi içinde bu değişimi yaşarken en büyük değiş̧im ve dönüşüm İnternet boyutunda gerçekleşmiştir. İnternet’te meydana gelen değişimler ve dönüşümler, toplumun beklentilerinin de değişmesi sonucunda ivme kazanmıştır. Bilginin dolaşımı, e posta gönderme ve alma, alışveriş, eğitim, haberleşme gibi pek çok amaca hizmet eden İnternet'in kullanım alanları, zamanla bireylere yetersiz gelmiş olacak ki kitle haberleşmede birbirinden farklı kanalları kullanmak gibi gereksinimler ortaya çıkmaya başlamıştır. Bu gereksinimler pek çok farklı boyutta gerçekleşmiş; insanların yaşadıkları hayata dair detayların diğer insanlar tarafından da görülmesini ve beğenilmesini istemeleri ve o insanların hayatlarından da aynı șekilde haberdar olmak istemeleri hayatımıza yeni bir kavramı getirmiştir: Sosyal Medya. Sosyal medya ortamı, bilginin çeşitlenmesinde, yaygınlaşmasında, biçiminde, içselleştirilmesinde, bilginin özgürce dolaşımı ve paylaşımında, bilgiye ulaşılması sürecinde belirleyici bir faktör olmuştur. Artık bireyler ulaşmak istedikleri pek çok bilgiye sosyal medya aracılığı ile ulaşabilirken, gündemi de yakından takip edebilme olanağı bulmakta, bizzat özne olarak bir haberin kaynağı ve yorumcusu olabilmektedirler (Babacan, Haşlak ve Hira, 2011; Kamiloğlu ve Uluğ Yurttaş, 2014).

Sosyal medya sanal bir iletişim ortamı arz ederken (Yegen, 2013) medya, kullanıcı ve teknoloji boyutlarının tümünün bütünleşik bir şekilde ortaya koyduğu bir kavramı ifade etmektedir (İşlek, 2012). Bu yönüyle sosyal medya, kullanıcılarının bilgilerini, görgülerini, ilgi alanlarını İnternet ya da mobil sistemler aracılığı ile paylaştıkları sosyal platformlara verilen addır (Sü Eröz ve Doğdubay, 2012). Sosyal medya katılım, açıklık, sohbet, toplum ve bağlantılı olma çerçevesinde paylaşım yapılmasını sağlayan yeni türden bir çevrimiçi medya grubudur ve sosyal medya platformları temel olarak altı boyutta şekillenmektedir. Bunlar: sosyal ağlar (MySpace, Facebook, Bebo vb.), bloglar, wikiler (wikipedia vb.), podcasts (Apple, Itunes vb.), forumlar, içerik toplulukları (Flickr, Youtube, del.icio.us vb.) ve mikrobloglardır (Twitter vb.) (Mayfield, 2008, s. 5-6). Bireyi merkeze alan bir yap1 arz etmesiyle gün geçtikçe kullanıcı sayısını arttıran sosyal medya, günümüzde yüz milyonlarca kullanıcıya ulaşmış durumdadır (Çildan, Ertemiz, Küçük, Tumuçin ve Albayrak, 2012). İșleyișini İnternet teknolojisine borçlu olan sosyal medya uygulamaları ise kullanıcılarına geniş bir diyalog ortamı sunmaktadır (Yağmurlu, 2011). Bu diyalog ortamında bireyler etkileşim sağladıkları kullanıcılar ile fikir ve görüşlerini paylaşabilme imkânı yakalamaktadır (Toksarı, Mürütsoy ve Bayraktar, 2014). Sosyal medya uygulamaları, bireylerin televizyon, gazete, radyo ve dergi gibi geleneksel iletişim araçlarına olan yönelimini azaltmasıyla yine bu bireylerin sosyal ve kültürel yaşamları üzerinde önemli etkiler ortaya çıkarmaktadır (Barutçu ve Tomaş, 2013). Sosyal medya coğrafi, fiziksel ve ekonomik engelleri ortadan kaldırarak bireylerin gerçek hayatta girmeleri mümkün olmayan gruplara girmelerini ve kendilerini daha rahat ifade edebilmelerini sağlamaktadır (Kakırman Yıldız, 2012).

Sosyal medya araçları, sadece kişisel kullanımdan doğan faydanın yanında, kurumların işleyişlerinde de kolaylıklar sağlaması, geliştirilen uygulamalarla birlikte marka ve ürünleri pazarlama faaliyetlerinin hızlandırılması ve daha geniş kitlelere ulaşılmasııın sağlanmasında oldukça önemli katkılar sağlamaktadır (Onat ve Aşman Alikılıç, 2008). Günümüzde işletmeler bu faydanın farkına varmış olacaklar ki ürün ve hizmetlerle ilgili pazarlama ve reklam stratejilerini sosyal medya üzerinden yapma eğilimine girmişlerdir (Haciefendioğlu, 2010).

Sosyal medya, sürekli güncellenebilen, çoklu kullanıma açık, sanal paylaşıma olanak tanıyan bir yapı arz etmesiyle en ideal mecralardan biri olarak ortaya çıkmaktadır. İnsanlar sosyal medyada düşüncelerini paylaşıp bu düşünceler üzerine tartışabilmekte, böylece yeni fikirler de ortaya çıkabilmektedir. Ayrıca sosyal medya aracılığı ile kişisel bilgilerin yanında fotoğraflar ve videolar paylaşılabilmekte, iş aranıp bulunabilmekte, gerçek dünya, sıkılmadan sanal ortamda yaşanabilmektedir. Sosyal medyanın bu güçleri elinde bulundurması, dikkatleri gün geçtikçe bu alana yöneltmekte ve yenilenen sanal dünyaya yeni bir kavramsal çerçeve çizilmektedir (Akıncı Vural ve Bat, 2010). Akıllı telefonlar, tablet bilgisayarlar gibi mobil cihazların kullanımının çoğalması, İnternet 
penetrasyonunun tüm dünya ülkelerinde artması ve bilginin hızlı dolaşımı da sosyal medyanın sahip olduğu bu güçleri günden güne arttırmaktadır (İşlek, 2012). Kullanıcı sayısının artması sosyal medyanın gücünü arttırmakta, sosyal medyada bilgi paylaşımı sağlamak ve içerik oluşturmak oldukça kolay bir hal almaktadır (Çildan ve diğerleri, 2012).

Birçok alanda ortaya koyduğu faydaların yanında eğitim alanında da önemli faydaları olan sosyal ağ teknolojileri, eğitim öğretim süreçlerinin aktif ve yaratıcı olması, iş birlikli öğrenme ile desteklenen bir yapıya getirilmesi, öğrenci-öğrenci, öğrenci-ders içeriği ve öğretmen-öğrenci etkileşiminin artması, öğrencilerin araştırma, sorgulama ve problem çözme gibi becerilerini işe koşmalarında oldukça faydalı olmaktadır (Gülbahar, Kalelioğlu ve Madran, 2010). Hızlı ve güncel olması, ucuz ve güvenilir olup iki yönlü ilişkiye olanak tanıması, bilgi tüketimi yaptırırken aynı zamanda bilgi üretimi yapmayı da sağlaması, bireylere seçme şansı ve hızlı cevap verme olanağı sağlaması da sosyal medya araçlarının bireylere sağladığ 1 faydalara örnek gösterilebilir (Öztürk ve Talas, 2015). Sosyal medya araçlarının kullanım amaçları doğrultusunda öğrenciler üzerinde akademik anlamda etkileri de şekillenmektedir. Ancak sosyal medya araçlarının sadece eğlence, vakit geçirme, oyun oynama gibi amaçlarla kullanılması durumlarında akademik anlamda olumlu etkilerin ortaya çıkmasından büyük ölçüde bahsedilemez. Buna karşılık eğitim öğretim ile ilintili sitelerin ve bilimsel içerikli yayınların takip edildiği durumlarda, sosyal medya kullanımının akademik anlamda olumlu yansımalarının mümkün olabileceği belirtilebilir. Bunun için de öğrencilerin güdülenmeleri ve motive olmaları gerekmektedir. Bu güdülenmenin sonucunda sosyal medya üzerinden akademik içerikleri paylaşmaya imkân sağlayan grupların kurulması, bu gruplara katılımın sağlanması ve paylaşımlar yapılması mümkün olabilmektedir (Akbaba, 2006).

Pek çok faydayı beraberinde getiren sosyal medya araçları ne yazık ki bireylere her zaman fayda sağlayamamakta; zaman zaman istenmeyen sonuçların ortaya çıkmasına neden olmaktadır. Sosyal medya araçlarının bilinçsiz kullanımından doğan olumsuz sonuçların geri dönüşünde ise zorluklar yaşanabilmektedir. Özellikle çocukların ve gençlerin sosyal medyayı bilinçsiz kullanmalarından doğan sorunlar daha sonraları kendilerini ve ailelerini zor durumlara düşürebilmektedir. Öğrenciler arasında İnternet ve cep telefonu kullanımının gün geçtikçe yaygınlaşmasıyla ortaya çıkan siber zorbalık, sosyal medya ortamında olumsuz yönde iletişimler kurulması, internet bağımlılı̆̆ bu sorunlara örnektir ve bu durumlar öğrenciler üzerinde önemli psikolojik baskıları da beraberinde getirmektedir (Özdemir ve Akar, 2011).

Sosyal medya kullanımının beraberinde getirmesi en muhtemel sorunlardan bir tanesi de internet bağımlılığıdır. İnternet bağımlılığı, internet aktivitelerine giderek artan bir zaman, para ve enerji ayırma durumuyla kendini gösterirken, çevrimiçi olunmadığında anksiyete, depresyon, boşluk ve yalnızlık gibi istenmeyen duyguları yaşatacak kadar tehlikeli boyutlara ulaşabilecek bir durumdur (Kandell, 1998, s. 12). İnternet bağımlılığı olan bireylerde internet kullanımını durdurmak, kontrol etmek veya kesmek gibi çabaların defalarca başarısızlıkla sonuçlanması, iş hayatında veya sosyal hayatta birtakım ilişkilerin tehlikeye atılması gibi durumlar dahi yaşanabilmektedir (Young, 1998, s. 238). İnternet ve sosyal medya bağımlılığı sonucu günlük hayatta yerine getirilmesi gereken sorumlulukların ertelenmesi de yaşanan sorunlardan bir tanesidir. Bu sorumlulukların ertelenmesi daha sonra yapılması gereken işlerin yığılmasına ve zaman kaybına neden olmaktadır (İşman ve Albayrak, 2014).

Sosyal medyanın artık her yerde ve kolay erişilebilir olması, operatörlerin kişileri konuşmaya ve mesajlaşmaya teşvik etmesi ve internetin akıllı telefonlarda yer almasıyla birlikte iletişim, insani ve zaruri bir ihtiyaçtan ziyade üretilmiş, yapay bir ihtiyaç haline gelmiştir (Göker, 2015). Ancak iletişim için sosyal medya platformlarında ve telekomünikasyonda meydana gelen bunca kolaylığın karşısında, iletişim sorunlarında azalma yerine bir artma olduğu görülmektedir. Fakat bilinen bir gerçek vardır ki o da iletişimsizlik, çevredeki kişilerle yeterince iletişim kurulamaması, ilişkilerde içtenliğin ve dostluğun bulunmaması yalnızlık duygusuna neden olmakta, bu durum da bireylerin mutsuz olmasına neden olup önemli kişilik sorunları yaşanmasına kapı aralamaktadır (Yüksel Şahin, 1998). Bir bireyin doğumundan itibaren etkileşim kurduğu pek çok kişinin onun kişiliğinde, ruh sağlığında, tutumlarında ve davranışlarında etkili olduğundan hareketle kişiler arası ilişkilerde problemler olmasının bireyleri derinden etkileyebileceği ve bu problemlerin temel sorunlardan olarak yaşamdaki yerini alabileceği belirtilebilir (Nacar ve Tümkaya, 2011). Özellikle günümüzde sanal iletişimin artması gerçek yaşama ayrılan zamanı azaltmakta, çocuklar ve gençler, gelişimleri üzerinde etkili olabilecek kişilerle yüz yüze iletişim kuramamaktadırlar. Bu durum da çocukları ve gençleri giderek yalnız ve içe dönük bir hale getirmektedir (Kakırman Yıldız, 2012). Oysa günümüzde bireylerin iletişim becerilerine daha fazla hâkim olması gerekmekte, özellikle insanlarla daha fazla bir arada olmayı gerektiren psikolog, hekim, hemşire, öğretmen, sosyal hizmet 
uzmanı, avukat ve satış uzmanı gibi bireylerin bu becerilerle daha fazla donanmış olmaları gerekmektedir. Çocukların ve gençlerin gelecekte bu mesleklerin birer adayı oldukları düşünüldüğünde, iletişim becerilerinin onlar için ne kadar önemli olduğu anlaşılmakta, bunu etkileyen sosyal medya kullanımlarının gerçek hayatla bir denge içerisinde olması gerekmektedir. Çünkü sosyal medya kullanımına ayrılan süre ile gerçek yaşama ayrılan süre dengelenemediği zaman iletişimin kolaylaşmaktan öte zorlaştığı görülmektedir (Korkut, 2005).

Görüldüğü üzere gelişen teknoloji ile birlikte sosyal medya, eğitim-öğretim ortamlarında ve kişilerarası ilişkilerde kendine önemli bir yer edinmiştir. Eğitim ortamının da kapsamının değişmesini sağlayan internet teknolojileri, eğitim kurumlarının ve insanların çağa ayak uydurması gerekliliğini beraberinde getirmiştir. Ağ tabanlı teknolojilerin bireylerin hayatına girmesiyle artık iletişim ve etkileşim kolaylaşmış, bireylerin bu ağların bir parçası olarak iletişime geçmeleri mümkün olmuştur. Yaşanan gelişmeler sonucunda bireylerin eğitimle ilgili ihtiyaçlarının karşılanmasında kullanılan teknolojilerde ve bu ihtiyaçlarda değişimler gözlemlenmiştir. Ayrıca bu teknolojiler eğitim sisteminin yapısını değiştirerek öğrenme ve öğretme faaliyetlerinde değişiklikler olmasını sağlamıştır. Eğitim de medya gibi geleneksel yapısından kurtularak biçim değiştirmiş, okul ve sınıf tabanlı formal yapıdan vazgeçilerek informal ve sosyal öğrenmeye odaklı bir yapıya bürünmüştür (Ekici ve Kıyıcı, 2012).

$\mathrm{Bu}$ çalışmada üniversite öğrencilerinin bilgiye ulaşabilmeleri, akademik bilgi paylaşımı yapabilmeleri ve sınıf içi etkileşimlerinin sosyal medya kullanımından ne şekilde etkilendiğinin ortaya konulması amaçlanmıştır. Bu amaçla çalışma grubunda yer alan öğrencilerle görüşmeler yapılmıştır. Görüşmelerden elde edilen verilerden yola çıkılarak öğrencilerin bilgiye ulaşabilmeleri, akademik bilgi paylaşımı yapabilmeleri ve sınıf içi etkileşimleri üzerinde sosyal medya araçlarını kullanmalarının etkili olup olmadığı, etkili ise bu etkilerin nasıl etkiler olduğu ortaya konulmaya çalışılmıştır. Çalışma kapsamında aşağıdaki sorulara yanıt aranmıştır:

1. Öğrenciler sosyal medya hakkında genel olarak neler düşünmektedirler?

2. Sosyal medya kullanımının öğrencilerin bilgiye ulaşabilmeleri ve akademik bilgi paylaşımı yapabilmeleri üzerinde olumlu/olumsuz etkileri nasıl şekillenmektedir?

3. Sosyal medya kullanımının öğrencilerin sınıf içi etkileşimleri üzerinde olumlu/olumsuz etkileri nasıl şekillenmektedir?

\section{Yöntem}

\section{Çalışma Grubu}

Bu araştırmanın çalışma grubu Ondokuz Mayıs Üniversitesi Eğitim Fakültesi'nde 2016-2017 yılında öğrenim görmekte olan 12 öğrenciden oluşmaktadır. Çalışma grubunun oluşturulmasında öğrencilerin akademik başarı ortalamaları dikkate alınarak, maksimum çeşitlilik örnekleme yöntemi kullanılmıştır. Bu kapsamda ortalama 60 kişiden oluşan bir sınıf düzeyindeki sıralamada en başarılı olan ilk 4 öğrenci, ortalama düzeyde olan 4 öğrenci ve en sonda yer alan 4 öğrenci seçilmiştir. Başarı seviyesindeki düşüklüğü okula devamsızlığından kaynaklanan öğrenciler, çalışma grubuna dâhil edilmemiştir. Örneklem grubunda yer alan tüm öğrencilerle görüşmeler yapılmıştır.

Tablo 1. Araştırmaya Katılan Öğrencilerin Özellikleri

\begin{tabular}{cccc}
\hline Öğrencinin Kodu & Cinsiyet & Yaş & $\begin{array}{c}\text { Akademik başarı } \\
\text { Sırası }\end{array}$ \\
\hline Ö1 & Kadın & 20 & 1 \\
Ö2 & Kadın & 21 & 2 \\
Ö3 & Kadın & 20 & 3 \\
Ö4 & Kadın & 22 & 4 \\
Ö5 & Kadın & 20 & 26 \\
Ö6 & Erkek & 20 & 27 \\
Ö7 & Erkek & 21 & 28 \\
Ö8 & Erkek & 22 & 29 \\
Ö9 & Erkek & 20 & 54 \\
Ö10 & Erkek & 21 & 55 \\
Ö11 & Kadın & 23 & 56 \\
Ö12 & Erkek & 20 & 57 \\
\hline
\end{tabular}




\section{Veri Toplama Aracı}

Bu çalışmada nitel araştırma yöntemlerinden görüşme yöntemi kullanılmış ve veri toplama aracı olarak literatür 1şığında geliştirilen görüşme formu kullanılmıştır. Bu form, uzman görüşü alınması ve örneklem grubu dışında yer alan bir öğrenci ile ön görüşme yapılması sonrasında gerekli görülen düzeltmelerle son şeklini almıştır.

Araştırılan olgu ve olayın bütüncül bir yapıya kavuşabilmesi için bazı ek yöntemlere (çeşitleme, katılımcı teyidi, meslektaş teyidi, vb.) ihtiyaç duyulmaktadır (Yıldırım ve Şimşek, 2013, s. 290). Bu yöntemlerin işe koşulması, yapılan çalışmanın geçerliği ve güvenirliği bakımından önemlidir. Geçerlilik ölçüm yapan aracın konuyu yanılgısız olarak ölçmesini (Aziz, 2010, s. 59) çalışmanın bulgularının anlamlılığını, çalışmanın inandırıcılığını, özgünlüğünü ve genellenebilirliğini ifade etmektedir (Miles ve Huberman, 2015, s. 278-279). Güvenilirlik ise nitel araştırmalarda, nicel araştırmalarda olduğundan daha farklı ele alınmaktadır. Burada araştırmaya başlanmasından da önceki süreçler, araştırma süreci, araştırmadan elde edilen verilerin analiz edilmesi süreci gibi nitel araştırma için oldukça önemli olan her bir boyutta titiz davranılması, araştırmanın güvenirliğini sağlamak bakımından önem arz etmektedir. Çünkü nitel araştırmalarda gerçeklerin bireylere ve ortama göre sürekli değişebildiği ve araştırmanın benzer gruplarla yapıldığında hep aynı sonuçlara ulaşmayı sağlayamayabileceği baştan kabul edilmektedir (Yıldırım ve Şimşek, 2013). Bu nedenle nitel araştırmalarda güvenirlik, çalışmanın her bir aşamasında yer alan her şeyin makul bir özen ile ele alınıp alınmaması ile yordanabilecek bir kavramdır (Miles ve Huberman, 2015, s. 278). Bu araştırmada geçerlik ve güvenirliğin sağlanabilmesi için öncelikle çalışma grubu dışında yer alan bir öğrenci ile ön görüşme yapılmış ve soruların anlaşılabilirliği yordanmaya çalışılmıştır. Bu görüşme, çalışma grubu ile yapılan 12 görüşmeye dahil edilmemiştir. Bu görüşme sonrasında yapılan düzenlemeler ile görüşme formu son şekline getirilmiştir. Ardından çalışma grubunda yer alan 12 öğrenci ile yapılan görüşmelerden elde edilen verilerin, bu verilerin analizlerinin ve yorumların başka bir araştırmacıya sunulması yöntemi ile çalışma tamamlanmıştır.

\section{Verilerin Toplanması ve Analizi}

Çalışma 2016-2017 eğitim öğretim yılında Ondokuz Mayıs Üniversitesi Eğitim Fakültesi’nde öğrenim görmekte olan 12 öğrenci ile gerçekleştirilmiştir. Örnekleme seçilen öğrencilerin tamamı görüşmeye katılmıştır. Yapılan görüşmeler katılımcıların izni doğrultusunda bir ses kayıt cihazı aracılığıyla kayıt altına alınmıştır. Elde edilen veriler betimsel analiz yolu ile analiz edilmiştir. Betimsel analizde elde edilen veriler daha önce belirlenmiş temalara göre düzenlenebildiği gibi görüşme veya gözlem sürecinde kullanılan sorulara ve boyutlara uygun olarak da sunulabilir. Görüşülen bireylerin görüşleri ise sık sık doğrudan alıntılar yapılarak ortaya konulur. Elde edilen veriler sistematik ve açık bir şekilde betimlenir, bu betimlemeler açıklanır ve yorumlanır, neden-sonuç ilişkileri ortaya konulur ve birtakım sonuçlara ulaşılır (Yıldırım ve Şimşek, 2013, s. 256). Bu çalışmada daha önceden belirlenmiş temalara göre düzenlenen veriler, betimsel analiz ile değerlendirilmiştir. Elde edilen verilerin analiz edilmesi için her bir öğrenciye bir kod verilmiştir. Öğrenciler ilk öğrenciden son öğrenciye olacak şekilde Ö1, Ö2, Ö3...Ö12 şeklinde kodlandırılmışlardır.

\section{Bulgular}

Çalışmanın bu bölümünde görüşme yapılan öğrencilerin sosyal medya ile ilgili görüşleri alınmış ve sosyal medyanın, bu öğrencilerin bilgiye ulaşabilmeleri, akademik bilgi paylaşımı yapabilmeleri ve sınıf içi etkileşimleri üzerinde nasıl etkileri olduğu değerlendirilmeye çalışılmıştır.

\section{Sosyal Medya Kavramının Öğrencilere Çağrıştırdıkları}

Çalışmanın bu bölümünde sosyal medya kavramının öğrencilerde yaptığı çağrışımlar ortaya konulmaya çalışılmıştır. Bu amaçla öğrencilere "Sosyal medya denilince aklınıza neler geliyor?” sorusu yöneltilmiştir. Verilen cevaplara bakıldığında sosyal medya denildiğinde öğrencilerin akıllarına Facebook, Instagram, Twitter, Swarm, Whatsapp, Tumblr, Snapchat ve Youtube gibi günümüzde popülerlik kazanmış olan sosyal medya araçlarının geldiği görülmektedir. Öğrencilerin bu konudaki ifadeleri aşağıdaki gibidir:

Ö1: Sosyal medya araçları denildiğinde aklıma bilgisayar, telefon ... Yani internetin girebildiği her türlü kitle iletişim aracı geliyor.

Ö2: Genellikle kullanıyor olduğum Facebook [aklıma geliyor]. 
Ö3: Sosyal medya araçları denilince aklıma Facebook, Twitter, ondan sonra Youtube gibi araçlar geliyor.

Ö4: Facebook, Instagram, Twitter ve Whatsapp.

Ö5: Illk başta Facebook geliyor aklima. Sonra Twitter, sonra Instagram, Tumblr ve Snapchat geliyor.

Ö6: Facebook, Instagram, Whatsapp, Twitter, Snapchat ve Swarm geliyor aklima.

Ö7: Sosyal medya araçları olarak aklima gelen online oyunlar, Instagram [genellikle onlarla ilgileniyorum]. Online oyun derken de sürekli satranç oynuyorum. Yabancılarla da oynuyorum. Onlarla etkileşime geçebiliyorum. Benden daha iyi oynayanları da izliyorum. Instagramda da yakın çevremi takip ediyorum. Benim için en önemlileri Instagram ve satranç. Facebook'a falan bakmiyorum. Çünkü Facebook günümüzde de gördügümmüz gibi çok kötü durumda.

Ö8: Sosyal medya sürekli bağımlı olduğumuz bir şey. Instagram, Facebook, Whatsapp, Twitter aklima gelenler.

Ö9: Aklima Facebook, Instagram, Twitter ve Whatsapp geliyor.

Ö10: Facebook, Twitter, Swarm ve Instagram geliyor.

\section{Öğrencilerin Kullandıkları Sosyal Medya Araçları}

Çalışmanın bu bölümünde öğrencilerin hangi sosyal medya araçlarını kullandıkları öğrenilmeye çalışılmıştır. Öğrencilerin Instagram, Youtube, Facebook, Swarm, Online Satranç, Twitter, Messenger, Whatsapp gibi sosyal medya araçlarını faal olarak kullandıkları görülmektedir. Akademik başarı sıralamasına göre öğrencilerin kullandıkları sosyal medya araçları arasında da önemli bir farklılık olmadığı görülmektedir ancak akademik başarı düzeyi düştükçe kullanılan sosyal medya araçlarında bir çeşitlilik olduğu görülmektedir. Akademik başarı düzeyi yüksek olan öğrencilerin en az 1 en fazla 3 sosyal medya hesabı kullandıkları görülürken akademik başarı düzeyi düşük olan öğrencilerin en az 3 en fazla 5 sosyal medya aracı kullandıkları görülmektedir. Bu durum kullanılan sosyal medya araçlarındaki çeşitliliğin akademik başarıyla ters orantılı olabileceğini düşündürmektedir. Öğrencilerden bir tanesi ise sosyal medya araçlarını kullanmakta neredeyse bağımlılık seviyesine geldiğini ancak yalnızca kendisinin değil arkadaşlarının da bu durumda olduğunu ifade etmektedir. Bu durum üzerinde kalınan ortamın da (yurt) etkisinin olduğunu vurgulayan bu öğrenci, zaman zaman derste dahi sosyal medya hesaplarına giriş yaptıklarını belirtmektedir. Öğrencilerin ifadeleri aşağıdaki gibidir:

Ö1: Evet kullanıyorum. Sosyal medya araçlarından Instagram gibi, Youtube gibi, kendi hesabım olmasa da kardeşimin hesabından Facebook gibi araçları kullanıyorum.

Ö2: Facebook ve Whatsapp'i kullaniyorum genelde ben.

Ö3: Evet bazılarını kullaniyorum. Mesela Youtube kullaniyorum.

Ö4: Facebook, Instagram ve Whatsapp'ı kullaniyorum.

Ö5: Ben sadece Facebook ve Instagram kullaniyorum.

Ö6: Hepsini olmasa da bir kısminı kullaniyorum. Facebook, Instagram bir de Whatsapp' kullaniyorum.

Ö7: Instagram, Online satranç, çok nadir olarak da Facebook.

Ö8: Facebook kullaniyordum. Şu an yeni kapattım hesabımı. Instagram ve Whatsapp kullanıyorum. Epey bir süredir sosyal medyayı kullaniyorum. Ama gitgide sanki biraz az zaman ayırlyormuşum gibi geliyor. Kaldı̆̆ımız ortamın çok etkilediğini düşü̈n̈̈orum. Yurtta kallyorum ben. Özellikle bu etkiliyor. Çevremdeki insanların da bağımlı olduğunu düşünüyorum. Onları da sürekli görüyorum. Aynı odada altı kişi kalıyoruz. Gözlemlerim sonucunda şunu söyleyebilirim herkes internet bağımlisl. Ben de o şekildeyim. Derste bile giriyoruz girmememiz gerektiği halde. 
Ö9: Instagram, Facebook ve Whatsapp hesaplarım var ama çok nadir giriyorum. Facebook'a belki iki haftada bir, Instagram 'a belki günde bir kere o da kim ne yapmış diye. Ama bilgisayar oyunlarına çok fazla zaman ayırlyorum.

Ö10: Kullaniyorum. Facebook kullaniyorum. Twitter, Instagram bir de Google Plus onu kullanıyorum. Başka yok.

Ö11: Birçoğunu kullanıyorum. Whatsapp, Facebook, Messenger, Swarm ve Instagram kullaniyorum.

Ö12: Tabii çoğunu kullanıyorum. Çok küçük bir yaştan bu yana Facebook hesabım var. Faal olarak Twitter ve Youtube kullanıyorum. Instagram'a çok fazla girmiyorum.

\section{Sosyal Medya Araçlarına Ayrılan Vakit}

Çalışmanın bu kısmında öğrencilerin sosyal medya hesaplarına günde ne kadar vakit ayırdıkları öğrenilmeye çalışılmıştır. Öğrencilerin sosyal medyaya günlük ayırdıkları vaktin en az 10 dakika en fazla 15 saat olduğu ortaya konulmuştur. Akademik başarı ortalaması yüksek olan öğrencilerin sosyal medya araçlarına günlük ortalama 1-2 saat ayırdıkları görülmekle birlikte bu öğrencilerden bir tanesinin günde 15 saatlik sosyal medya kullanımı ile diğer öğrencilerden farklılaştığı görülmektedir. Akademik başarı düzeyi ortalama olan öğrencilere bakıldığında sosyal medyaya 1 ila 5 saat vakit ayrıldığı görülmektedir. Akademik başarı ortalaması düşük olan öğrencilere bakıldığında ise bu öğrencilerin en az 3 en fazla 10 saati sosyal medya kullanımına ayırdıkları görülmektedir. Bu öğrencilerden bir tanesinin sosyal medya kullanımına günlük 10-15 dakika ayırdığ görülmektedir. Böyle örnekler olmakla birlikte sosyal medya kullanımına ayrılan vakit arttıkça akademik başarı ortalamasının da düştüğü belirtilebilir. Günde 15 saatini sosyal medya hesaplarına ayıran öğrencinin akademik başarısının yüksek olduğu, günde 10-15 dakikasını sosyal medya hesaplarına ayıran öğrencinin akademik başarısının düşük olduğu durumlar olduğu görülmektedir. Fakat bu durumlar bir frekans düşüklüğü olarak değerlendirilmekte, grup üzerinde bir genelleme yapılmasına izin vermemektedir. Öğrencilerin sosyal medya araçlarına ayırdıkları vakit ile ilgili ifadeleri aşağıdaki gibidir:

Ö1: Çok yoğun değil genellikle ders dahilinde çalıştı̆̆ım için, vakit geçirme adına 1 veya 2 saatlik zaman dilimimi ona ayırıyorum.

Ö2: Gününe göre değişiyor. Ama evde olursam biraz daha az bakıyorum. Burada da aynı şekilde en fazla 2 saat harclyorum.

Ö3: Günde 1-2 saat falan ayırlyorum herhalde öyle çok değil.

Ö4: Hesaplayamam. Sürekli elimde telefon. Sürekli bakıyorum. Sadece ders çalışırken telefonu dikkatimi dăğtmasın diye kendimden uzak bir yere koyuyorum. Günde 15 saat harclyorum.

Ö5: Dönemine göre değişiyor. Vize haftalarında çok fazla vakit ayırıyorum. Ama normalde çok da fazla ilgilenmiyorum. Günde en fazla 1-2 saat.

Ö6: Yoğun bir vakit ayırıyorum. Okulda olduğumda pek kullanmıyorum. Mesela ders 17:15'te başllyorsa bu süre içerisinde bakmamaya çallşlyorum. Ama yurtta kalan bir ögrenciyim. Yurtta zamanımı kesinlikle sosyal medyada harcıyorum. Bu da günde ortalama bir 4-5 saati buluyor.

Ö7: Satrancı ayrı bir şey olarak düşünelim. Çünkü orada zekâ geliştirmeye yönelik bir amaç var. Benim amacım orada epey ilerlemek olduğu için 2-3 saat kadar bir vakit harclyorum. Instagram 'da 2 saat veya 1 saat harclyorum. Günde toplam 5 saatimi internette harclyorum ama 3 saatini faydal görüyorum.

Ö8: Kısa sürelerle ama çok sık giriyorum ben sosyal medya hesaplarıma. Günde en az bir buçukiki saat ayırlyorum yani.

Ö9: Çok az. Oldukça az. Günde 10-15 dakika. 
Ö10: Günde ne kadar vakit ayırlyorum... Evde olduğum zaman bilgisayarım her zaman açık oluyor zaten. Bazı oyunlar oynuyorum o zaman sürekli arka planda açık olur. Bu vakit her gün değişiyor. Okuldan eve gittiğim zaman ne kadar vakit varsa işte... 8 saat diyebilirim.

Ö11: Hemen hemen günümün yarısını ayırlyorum. 8-10 saat ayırıyorum.

Ö12: O gün içinde yapacağım işlere göre değişiyor aslında. Bazı günler laptopun başında işim yoksa 3-4 saati bulabiliyor ama yoğun bir gün ise sadece telefondan bir 15-20 dakika da baksam yetiyor yani. Ben sosyal medyaya ne kadar zaman ayıracă̆ım konusunda kendimi kontrol edebiliyorum.

\section{Sosyal Medyayı Kullanma Amaçları}

Sosyal medya araçlarının kullanım alanları birbirinden farklı ve oldukça çeşitlidir. Örneğin Instagram genel olarak fotoğraf ve video paylaşımı yapmak ve mesajlaşmak için kullanılırken Facebook'un kullanım alanı daha geniştir. Burada fotoğraf, video paylaşımı ve mesajlaşmanın yanı sıra belli gruplar kurulması ve bu grupların bir araya gelmesine uygun amaca hizmet eden paylaşımlar yapılması da mümkün olmaktadır. Youtube ise video paylaşımı yapmaya izin veren yapısıyla her gün milyonlarca kişiye hizmet vermekte olan bir platformdur. Bireyler burada isterlerse kendi kanallarını oluşturabilmekte ve buradan seslerini geniş kitlelere duyurabilme imkânı yakalayabilmektedirler. Whatsapp ise büyük ölçüde mesajlaşmak için kullanılmakta, belli gruplar kurulması ile bu gruplarda yer alan kişilerin birbirleri ile sanki aynı ortamdaymışçasına sohbet edebilmelerine imkân tanımaktadır. Ancak bunun yanında haberleşme, eğlence, alışveriş yapma ve eğitim gibi imkânlara da artık bu platformlar sayesinde ulaşılabildiği görülmektedir.

Çalışma grubunda yer alan öğrencilerin, sosyal medya araçlarını genel olarak eğlence, iletişim, insanları, sayfaları ve haberleri takip etme, akademik çalışma, can sıkıntısını giderme, film izleme gibi amaçlarla kullandıkları görülmektedir. Akademik başarı düzeyi yüksek olan öğrencilerin sosyal medya hesaplarını genel olarak eğlence, iletişim, kişileri takip etme, derslerle ilgili notları derleme, kişisel gelişimi sağlama ve akademik anlamda kendilerine katkı sağlayacak videolar izleme gibi amaçlarla kullandıkları görülürken, akademik başarı düzeyi düşük olan öğrencilerin sosyal medya hesaplarını genel olarak eğlence, haberleşme, can sıkıntısını giderme, film izleme, ders çalışma, kişileri ve sayfaları takip etme, akademik çalışma gibi amaçlarla kullandıkları görülmektedir. Öğrencilerin yaptıkları açıklamalardan yola çıkılarak akademik başarı düzeyi yüksek olan öğrencilerin sosyal medya araçlarını akademik başarılarına katkı sağlayabilecek veya bu başarılarına sekte vurmayacak şekilde kullandıkları görülürken akademik başarı düzeyi düşük olan öğrencilerin genel olarak bu kaygıda olmadıkları görülmektedir. Öğrencilerin açıklamaları aşağıdaki gibidir:

Ö1: Genel itibariyle çok yoğun bir ders programım var. Devamlı çalıştı̆̆ım için aklımı dă̆ıtmak amacıyla kullanıyorum. Eğlence amaçlı kullanıyorum. Yemek yapmak hobimdir çok severim mesela yemek tariflerinin olduğu sayfalar, giyim sayfaları bunlara genellikle vakit ayırıyorum.

Ö2: Ben arkadaşlarımla konuşmak ve kimin ne yaptığını görmek amacıla genellikle Whatsapp'l kullanıyorum. Sınav zamanları arkadaşlarımın gönderdiği ders ile ilgili içeriklere bakıyorum. Notlar buradan derliyorum.

Ö3: Sosyal medya araçlarımı kimi zaman eğitim, kimi zaman ĕ̆lence için günümün yoğunluğuna bağll olarak değişen şekillerde kullanıyorum. Okul vaktiyse genelde eğitimime yönelik kullanıyorum. Mesela Youtube var diğerlerine nazaran daha öne çıkmayan bir yapısı var. Daha çok video yüklemeleriyle var ve kişiler kendilerine kanallar açarak buradan çeşitli şeyleri paylaşlyorlar. Hatta bazen kendi günlük yaşamlarını paylaşlyorlar. Onları takip ediyorum. Bazen bazı hocaların ya da bazı öğretmenlerin kendi branşlarına özel kanallarl oluyor ve orada ders anlatıyorlar onlara bakıyorum. Bunun dışında bazen yabancı Youtuberlar oluyor. Onların değişik yaşam tarzlarını ve ülkelerinin coğrafyasını orada daha rahat görmüş oluyorum. Ama eğer okul dışındaysam daha çok eğlenmek ve kültürel olarak kendimi geliştirmek amacılla kullanıyorum.

Ö4: Facebook'ta haberleri çok takip ediyorum. Özellikle Samsun haberlerini çok takip ediyorum. Instagram'da arkadaşlarımı takip ediyorum. Whatsapp zaten tüm iletişim aracımız artık sms diye bir şey kalmadl. 
Ö5: Bilgi edinmek, uzakta olan tanıdıklarımla görüşebilmek amaclyla [kullaniyorum]. Hakikaten şu an ben de sorguluyorum. Ne amaçla kullaniyorum ki...

Ö6: Benim önceliğim eğlence diyebilirim. Çünkü komedi sayfaları takip ediyorum. Eğitim amaçlı da kullaniyorum. Mesela KPSS sayfalarl da takip ediyorum.

Ö7: Ben eğlence ve haberleri takip etme amacıyla kullanıyorum. Satrancı da bilgi amaçlı kullaniyorum.

Ö8: Tamamen birilerini takip etmek, arkadaşlarımı görmek [amacıyla kullanıyorum]. Instagram kullaniyorum. Sürekli orada geziyorum. Belli bir amacım da yok. Sadece eğlence amacım var. Biraz bağımlılık bu. Hiçbir faydasını da görmüyorum. Whatsapp'ı biraz yararlı buluyorum

Ö9: Genelde haberlere bakiyorum. Dünyada neler olduğundan haberdar olmaya çallşlyorum. Arkadaşlarım ne yapmış, nerelere gitmiş onları ögrenmeye çalışlyorum.

Ö10: Can sıkıntısını gidermek gibi amaçlarla kullanıyorum. Değişiyor. Tam olarak belli bir amacım yok. Ana ekranda ne varsa onlara bakıyorum. Sosyal medyayı özel bir amaçla kullanmiyorum yani.

Ö11: O gün arkadaşlarımın neler yaptı̆̆ın görmek veya sadece vakit geçirmek, film izlemek, bazı konularda bilgi edinmek için kullanıyorum. Ders çalışırken anlamadığım bir kelimeye bakmak, notumun olmadığı konular varsa bu notlara ulaşmak amaciyla kullaniyorum.

Ö12: Ben daha çok eğlenmeye ve zaman geçirmeye yönelik kullanıyorum. Twitter'da takımımı takip ediyorum. Birkaç haber sayfasını takip ediyorum. Birilerini takip etme amacında değilim. Facebook'u da sıradan amaçlarla, zaman geçirmeye yönelik kullaniyorum.

\section{Etkileri}

Sosyal Medya Kullanımının Bilgiye Ulaşmak ve Akademik Bilgi Paylaşımı yapmak Üzerindeki

Öğrencilere sosyal medya kullanımlarının bilgiye ulaşmaları ve akademik bilgi paylaşımı yapabilmeleri üzerinde etkili olup olmadığı sorulmuş, eğer etkili ise bu etkinin nasıl gerçekleştiğini açıklamaları istenmiştir. Sosyal medya kullanımının bilgiye ulaşmak ve akademik bilgi paylaşımı yapabilmek üzerinde olumlu etki yaptığını belirten öğrenciler, buna pek çok kanıt göstermişlerdir. Sosyal medya kullanımının stresten uzak kalmayı sağlaması, motivasyon üzerinde olumlu etkiler yapması, boş zaman geçirmeye katkıda bulunarak öğrencilerin zihnini rahatlatması, tarih, coğrafya ve Kamu Personeli Seçme Sınavı (KPSS) konularında bilgi edinmeye imkan tanıması, mesleki ve akademik anlamda bilgi almayı sağlaması, ders notu paylaşmayı mümkün kılması olumlu etkilere gösterilen kanıtlardır. Bunların yanı sıra öğretici videolar izlenmesi yoluyla ülkelerin ve kültürlerin tanınmasına olanak sağlanması, bilgi kaynaklarına erişimin kolay olması, soru paylaşımı yapılması gibi durumlar da sosyal medya kullanımının öğrencilere fayda sağladığı durumlardır. Öğrencilerin not ve soru paylaşımı konusunda Whatsapp uygulamasının da önemine vurgu yaptıkları görülmektedir. Öğrencilerin ifadeleri aşağıdaki gibidir:

Ö1: Akademik olarak doğrudan etkilediğini düşünmüyorum ama motive olmamı sağllyor. O stresli durumlardan biraz daha uzaklaşmamı sağllyor. Bu şekilde de bana motivasyon anlamında bir artısı olduğunu düşünüyorum. Benim için sosyal medya kullanımı rahatlama aracı gibi bir şey. Devamlı ders çalışmaktan ziyade kafamı başka bir yere yorabilmemi sağllyor. Daha sonra ders başına oturduğumda daha fazla motive olmamı sağllyor. Benim için eğlence aracı, vakit geçirme aracı gibi bir şey yani. Kendi meslek alanımla ilgili coğrafya, tarih, KPSS gibi alanlarda bilgi edinmemi sağllyor. Memurluk gibi alanlarla ilgili yorumlarl görebilmemi sağllyor. En basitinden bu işlerle uğraşan insanların bu alanla ilgili yorumlarını okuyabiliyorum. Bu anlamda gelecekle ilgili fikir edinmem adına ve motive olmam adına da ekstra bir artısı oluyor. Ama bunların haricinde de çok büyük bir değiş̧ken değil benim için.

Ö2: Facebook ya da Whatsapp üzerinden arkadaşlarımın kendi notlarını paylaşmaları benim açımdan iyi oluyor. Hangi konuda eksik var, neyi daha farklı yazmışlar, onların yorumları nasıl buna bakiyorum. Bu nedenle yararlı oluyor benim için. 
Ö3: Bölümümün coğrafya ile etkileşimi var ve coğrafyada değişik Youtuberlar'nn kendi ülkeleri hakkında gezerek çektikleri videolar var. Bunları izlediğimde o ülkeler hakkında farkında dahi olmadan farklı bilgiler elde etmiş oluyorum. Dolayıslyla gitmeden kültürünü ögrenmiş ve etkileşim yaşamış oluyorum. Bazen öğretici videolar izleyerek eksiklerimi kapatabiliyorum. Bana bu şekilde artssı oluyor. Olumsuz etkilerine bakarsak mesela ilk önce bir veya birkaç video ile başliyorsunuz eğer kendinizi durduramazsanız saatlerce çeşitli videolar izleyebilirsiniz. Tamamen kendi iradenize bağll. Çok renkli geldiği için birç̧ok video izlerken saatler harcıyorsunuz. Bu da vakit kaybına neden oluyor. Ama ders çallşmamı çok da engellemiyor. Çünkü günlük plan yapıyorum. Ders saatime yaklaşmadan genellikle merak ettiğim ne varsa o saat içerisinde tamamliyorum ki ders çalışırken keşke şuna baksaydım diyerek dersi bölmeyeyim diye. O zaman neyi merak ediyorsam bakiyorum. Sonra derse oturuyorum ve tamamen derse konsantre oluyorum. Sosyal medya kullanimim beni akademik olarak genellikle olumlu etkiliyor.

Ö4: Aklıma bir şey takıldığında kitaptan aramaktansa direkt internetten baklyorum artık. Çünkü bir saniye sürmüyor. Kitapta onu aradım buldum diyene kadar çok vakit geçiyor. Whatsapp üzerinden sürekli not paylaşımı gerçekleştiriyoruz arkadaşlarla.

Ö5: Soru paylaşımlart yapıyoruz. Mesela geçenlerde Sinıf Yönetimi sinavim vardı. Facebook'ta açıöğretim sinavları için paylaşılan sorular vard. Bu soruları çözdüm ve bana fayda da săgladı.

Ö6: Mesela sinıfin Whatsapp grubu var oradan arkadaşlar not gönderiyorlar. Eğitim sayfaları takip ediyorum. O şekilde yararı oluyor sosyal medyanın.

Ö8: Not alıp vermede kullanıyorum. Notların fotoğrafların çekiyoruz. Arkadaşlarım gönderiyor ben alyyorum. O yönden olumlu.

Ö9: Facebook'ta takip ettiğim tarih sayfalarının olumlu etkisi var diyebilirim. Orada kulağımda kalan birkaç şey olumlu etki yapabiliyor.

Ö11: Bilmediğim birçok şeyi oradan [sosyal medyadan] öğrenebildiğim oluyor. Alaninda bilgisi olan kişilerden yardım da alabiliyorum. Facebook'ta Sosyal Bilgiler ile alakalı KPSS soruları sayfaları veya Sosyal Bilgiler Öğretmenliği ile ilgili bazı gruplar var. Sinıfimızın bir grubu var. Buralarda soru paylaşımları oluyor. Bunlar işime yarıyor. Whatsapp'ta slnıfta kendimi yakın hissettiğim arkadaşlarımla not alışverişi yapıyorum. Bunlar bana akademik anlamda olumlu etki yapabiliyor.

Ö12: Bazı sayfaları takip ediyorum. Tarih, KPSS soru sayfaları gibi. Instagram'ı daha çok o amaçla kullanıyorum. Ama Facebook'un bu anlamda pek bir katkısı olduğunu düşünmüyorum. Ama dediğim gibi ikinci sinuftan altı dersim var alttan. Onların olmasının nedeni sosyal medya kullanımım değil.

Öğrencilerin sosyal medya kullanımları bilgiye ulaşmaları ve akademik bilgi paylaşımı yapabilmeleri üzerinde her zaman olumlu etkiler ortaya çıkarmamaktadır. Öğrenciler, sosyal medya kullanımlarının olumsuz etkilerine de pek çok kanıt göstermişlerdir. Bunlar; derslerin olumsuz etkilenmesi, konsantrasyon bozukluğu, ders çalışmanın ertelenmesi, vakit kaybı, motivasyon bozukluğu gibi etkilerdir. Sosyal medyada akademik çalışmalar için başlayan bir görüşmenin boyut değiştirip eğlenceli konuşmalara dönüşmesi, daha fazla zaman geçirme isteğinin vakit kaybını beraberinde getirmesi, gereksiz bilgi yığınının öğrencilerin zihnini doldurması ve sağlığa olan zararı da sosyal medyanın öğrenciler tarafından işaret edilen olumsuz yönleridir. Öğrencilerin ifadeleri aşağıdaki gibidir:

Ö1: Genel itibariyle bir şeye bakıp da çok dikkatimi çektiğinde daha sonrasinda ders yapmam gerekiyorsa motive olma anlamında bana dezavantaj oluşturuyor. Aklımın onda kalması, daha fazla zaman geçirme isteği... Bu da adapte olabilmemi kimi zaman olumsuz etkiliyor.

Ö2: Bazen konuşmalar fazla uzayınca dersten dışarı çıkıyoruz ve başka bir şey konuşmaya başliyoruz. Arkadaşlarla ders konuşma amacıyla başlayıp eğlence amaçl konuşmaya dönmek benim için kötü oluyor. O sırada diyorum ki internet kesilsin. Ama arkadaşıma da ayıp olmasın istiyorum. Konuşmaya devam ediyorum ama vicdani olarak ders çallşamadı̆̆ım için kendimi rahatsiz hissediyorum. Bu vakit kaybı beni olumsuz etkiliyor.

Ö3: Derse ara verdiğimde başlarsam 15 dakika ile başlayan ara 1 saati buluyor. 
Ö4: Çok vakit kaybediyorum. Çok olumsuz etkiliyor beni. Biz onu yönlendiremiyoruz. O bizi yönlendiriyor. Vaktimin çoğunu orada kaybediyorum. Saçma sapan şeylere dahi saatlerce takılabiliyorum. Oysa o saati daha iyi değerlendirebilirim.

Ö5: Telefonu elime alıp iki dakika bakayım dediğimde bir bakmışım saatler geçmiş. Vakit kaybı, gereksiz bilgi ile beynimi boşuna doldurmam ve sağlığıma olan negatif etkileri var. Gözlerime zararı var. Derslerime de olumsuz yanslyor.

Ö6: Mesela dersin başına oturuyorum. Cep telefonum açıksa bir bildirim geliyor. İster istemez konsantrasyonum dağllyor. Hemen cep telefonuma bakmak istiyorum. Ister istemez aklım oraya gidiyor. Zaten ben ders de çalışmıyorum.

Ö8: Ders çalışmamı etkiliyor. Çoğu zaman biraz sonra çalışırım. Biraz daha internette takılayım, oyun oynayayım derken olumsuz olarak daha çok etkileniyorum. Vaktimi harcıyorum. Ders çalışmıyorum. Genelde olumsuz. Ben işin ciddiyetinin de farkındayım. Çok kullanıyorum. Bırakmam gerekiyor da diyorum ama bırakamıyorum. Azaltsam da aradan bir süre geçtikten sonra yine dayanamıyorum. Azaltsam da sona erdiremiyorum kullanımımı.

Ö9: Oynadı̆̆ım oyunlar derslerim üzerinde olumsuz bir etkiye sahip. Çünkü bazen ders çalışırım diye not alıyorum eve giderken arkadaşlarımdan. Oturup çalışmak için kâğıtları önüme alıyorum ama biraz zaman geçince sıkılıyorum. Oyun oynuyorum. Belki oyun oynamayacak olsam, sıklsam bile kendimi biraz zorlarım. Ama daha ĕ̆lenceli bir seçenek olunca diğer tarafta, ders çalışmak yerine oyun oynamay tercih ediyorum.

Ö11: Olumsuz olarak gereksiz olan birçok şeye vakit ayırabiliyorum. Saatimin çoğunu orada geçiriyorum. Çok vakit kaybediyorum.

Sosyal medya kullanımlarının bilgiye ulaşmaları ve akademik bilgi paylaşımı yapabilmeleri üzerinde hiçbir etkisi olmadığını belirten öğrenciler de olmuştur. Bu öğrencilerden bir tanesi sosyal medyayı boş zaman değerlendirme aracı olarak kullandığını ifade ederken, diğer iki öğrenci de yine sosyal medya kullanımlarının bilgiye ulaşmaları ve akademik bilgi paylaşımı yapabilmeleri üzerinde bir etkisi olmadığını belirtmişlerdir. Bu iki öğrenci akademik başarı düzeyi bakımından başarı seviyesi düşük olan öğrencilerdir. Öğrencilerin ifadeleri aşağıdaki gibidir:

Ö7: Belki satrancın bir etkisi vardır ama Instagram'ın hiç etkisi yok. Yurtta kallyorum boş vaktim çok. Bu vakitleri değerlendirmek için kullanıyorum zaten.

Ö10: Sosyal medya kullanımım bana akademik olarak olumlu veya olumsuz hiçbir etki yapmıyor. Kullanmayayım dersem kullanmam. Mesela telefonum bozuk. Telefon benim için bir anlam ifade etmiyor şu an. Bă̆ımlılık seviyesinde değil yani. Ben aslında üniversite sınavına hazırlanırken psikoloji okumak istiyordum. Onun için çok çalıştım. Psikolojiyi kazanamadım. Bu bölüm geldi. Ama ben ögretmenlik yapmak istemiyorum. Bu benim için ikinci üçüncü planda geliyor. Mesela bir esnaf olurum veya esnaf olduktan sonra bir özel üniversitede psikoloji okurum. Hiçbiri olmazsa o zaman ögretmen olurum. Bölümdeki başarı durumum tamamen benim bireysel olarak çalışmayı istemememden kaynakl.

Ö12: Şu anda bulunduğum durum sosyal medya kullanımımla alakalı değil. Alttan kalan derslerim de ikinci sınıftan zaten. İkinci sınıfta zor bir dönemden geçtim. Bazı özel sorunlarım vardı. O yüzden akademik olarak sosyal medyadan etkilenmiyorum.

\section{Sosyal Medya Kullanımının Sınıf İçi İlişkiler Üzerindeki Etkisi}

Üniversite dönemi bireylerin eğitim ve öğretim amacıyla ailelerinden ayrılarak kendi ayakları üzerinde durmaya başladıkları en önemli evrelerdendir. Öğrenciler, bu süreçte yeni bir şehre ve hayata adapte olmaya çalışırlarken yeni arkadaşılık ortamları da bu uyum sürecinde etkili olmaktadır. Bu süreç kimileri için kolay olurken kimileri için de zor ve karmaşık bir hal almaktadır. Bunun temelinde pek çok faktör bulunmaktadır. Bazı öğrenciler daha girişken ve sosyal oldukları için yeni arkadaşlıklar kurmakta ve bu arkadaşlıkları sürdürmekte daha başarılı olurken, bazı öğrenciler de bu süreci aynı şekilde sürdürememektedirler. 
Çalışmanın bu bölümünde öğrencilerin sosyal medya kullanımlarının sınıf içi ilişkileri üzerinde etkili olup olmadığı ortaya koyulmaya çalışılmış, eğer etkiliyse bu etkinin nasıl olduğu ile ilgili öğrencilerden bilgi alınmaya çalışılmıştır. Bazı öğrenciler sosyal medya kullanımlarının sınıf içi ilişkileri üzerinde olumlu etkileri olduğunu ifade ederken, bazı öğrenciler de olumsuz etkileri olduğunu ifade etmişlerdir. Sosyal medya kullanımının sınıf içi ilişkilerini olumlu yönde etkilediğini belirten öğrenciler, günlük hayatta iletişim içinde olmadıkları kişilerle sosyal medya sayesinde iletişim kurabildiklerini belirtmişlerdir. Bu öğrenciler, bu durumun günlük hayattaki ilişkilerine de olumlu yansıdığını ifade etmişlerdir. Kişiler hakkında sahip olunan ön yargıların yıkılmasında, organizasyonların düzenlenmesinde, sınıf içinde bir kaynaşma sağlanmasında, yüz yüze iletişimin kolaylaşmasında sosyal medyanın olumlu etkileri olduğunu ifade eden öğrenciler bulunmaktadır. Öğrencilerin ifadeleri aşağıdaki gibidir:

Ö1: Bazı insanlarla hiç muhabbetim olmadı̆̆ halde onlarla ilgili fikir edinebiliyorum mesela. İşte şu kişi şunu yapıyormuş, bu kişi bunu yapmış gibi... Insanlarla birebir tanışıklı̆̆ımız olmasa da internet aracılı̆̆lyla onlarla ilgili fikir sahibi olmuş oluyorum. Bu da sosyal ilişkilerimi olumlu yönde etkiliyor.

Ö2: Sınıfta benimle hiç konuşmayan bir insanın Whatsapp 'ta benimle konuştuğunu görünce ona olan ön yargım yıkılıyor. Sessiz duran birinin esprili biri olduğunu görüyorum. Yanlış tanımışım diyorum. Arkadaş olunabilecek birisi diye düşünüyorum. Daha çok olumlu etkiliyor.

Ö4: Illk geldiğimiz zamanlarda kimse birbiriyle konuşamıyordu. Ama internet üzerinden konuşulmaya başlandı. Sinıfta ancak o şekilde selamlaşılmaya başlandı. Yoksa kimse kimsenin yüzüne bakmıyordu. Internet üzerinden konuşmak, arkadaşlık kurmak daha kolay geldi. Mesela ben şu an çok samimi olduğum iki arkadaşımla daha okula gelmeden internetten tanıştım. O şekilde samimi olduk. Hala da arkadaşlı̆̆ımız devam ediyor.

Ö5: Normal hayatta görüşmediğim insanlarla orada görüşüp not paylaşımı yapıyorum. Bu şekilde bir faydası var. Bazı derslerle ilgili kurduğumuz gruplar var. Oradan konuşuyoruz. Günlük hayatta olmayan iletişimi olur hale getiriyoruz. Aslinda sadece bu olumlu etkisi.

Ö6: Olumlu açıdan mesela sınıfta yüz yüze konuşamadı̆̆ım insanlarla sosyal medya aracılığıyla arkadaş olabiliyorum. Takipleşebiliyorum. Daha kolay iletişim kurabiliyorum.

Ö8: Mesela biz sosyal medya aracılı̆̆lyla konuşup piknik düzenlemiştik. Birbirimizle kaynaşmamızda olumlu etkisi olmuştu bu anlamda. Şu an için sınıf adına olan tek yararı olarak bunu örnek gösterebilirim.

Ö11: Insanlar çoğu zaman sınıfta birbirinden utanıp çekiniyor, birbiriyle iletişime geçmiyorlar. Ama sosyal medya üzerinden ne de olsa görmüyorum diyerek daha samimi iletişime geçiyoruz.

Ö12: Mesela akşamlarl Whatsapp'tan konuştuğum bir arkadaşımla gündüz okulda daha rahat iletişim kurabiliyorum. Çünkü neye ne tepki verebileceğini tahmin edebiliyorum. Kendime yakın hissetmediğim biriyle zaten mesajlaşmam. Olumlu etkiliyor sosyal medya sınıf içi ilişkilerimi.

Sosyal medya kullanımının sınıf içi ilişkileri olumsuz etkilediğini belirten öğrenciler de bulunmaktadır. Bu öğrenciler, sosyal medya kullanımının ön yargılı olmaya sebebiyet verdiğini ve yüz yüze ilişkiler kurulmasını zorlaştırdığını, sosyal medya platformlarında siyaset ve futbol konularında tartışmalar yaşanabildiğini ifade etmişlerdir. Öğrencilerin ifadeleri aşağıdaki gibidir:

Ö1: Bazen ön yargılı olmama neden oluyor. Çünkü hiç tanımadı̆̆ım insanlarla ilgili sadece kitle iletişim araçlarl yoluyla fikir sahibi oluyorum. Hiç yoktan onunla ilgili bir ön profil oluyor benim aklımda ve bu fikirlerle onlara yaklaşıyorum bu da sınıf içi ilişkilerimi olumsuz etkileyebiliyor.

Ö4: Bazen de gereksiz konular tartlşlllyor. Siyasi konularda veya futbol konusunda gereksiz muhabbetler oluyor. Insanlar ağzına geleni söylüyor. Düşünmeden konuşuyorlar. Belki de yüz yüze olsalar söyleyemeyecekleri şeyleri sosyal medyada söyleyebiliyorlar. Ben böyle bir şey yaşamadım ama etrafimda yaşaniyor.

Ö5: Aslında sosyal medya kullanmanın iletişim anlamında daha çok olumsuz etkileri var. Çünkü bir araya geldiğimizde herhangi bir şekilde bir paylaşım yapılmıyor. Herkesin elinde bir telefon var. 
Herkes onunla ilgileniyor. İletişim sıfir. En başta iletişimi etkiliyor. İletişimsizlik en önemli olumsuz etkisi.

Ö6: Tembelliğe sürüklüyor. Yüz yüze iletişime geçmek varken telefonla haberleşmek öncelikli oluveriyor. Samimi ilişkiler kurulamıyor bu nedenle bazen. Sosyal medyayı da dozunda kullanmak lazım diye düşünüyorum.

Ö7: Tamamen olumsuz etkiliyor. Örneğin ders aralarında herkes telefonuyla uğraşıyor. Ben genelde telefonda konuşuyorum. Herkes mesajlaşıyor. Derste de mesajlaşıllyor. Whatsapp olmasa belki çoğu kişi daha iyi bir konumda olur. Her şekilde olumsuz yani sosyal medya.

Ö11: Insanlar birbirine [sosyal medya ortamında] daha yakın davranıyor ama yüz yüze öyle bir etkileşim olmuyor bizim sınıfta. Bazen sosyal medya üzerinden paylaştı̆̆ımız sözler yanlış anlaşılabiliyor. Insanlar bunu yanlış anlayarak tartışmaya sürükleyebiliyor. O tartışma büyüyor ve insanlar arasında sorunlara yol açıyor. Bizim sınıfımızda zaten çok güzel bir etkileşim ortamı yok.

Sosyal medya kullanımının sınıf içi ilişkilerine hiçbir etkisi olmadığını belirten öğrenciler de olmuştur. Bu öğrencilerin ifadeleri de aşağıdaki gibidir:

Ö3: Sınıf içi ilişkilerimde sosyal medya kullanımımın bir etkisi yok. Çünkü orada okuldan tanıdı̆̆ım birileri yok. Dolayısıyla çok bir etkileşimim yok. Çünkü kullandığım sosyal medya platformu birileriyle etkileşim üzerine değil paylaşım üzerine kurulu.

Ö7: Tanımadı̆̆ım insanlarla sosyal medyada etkileşime geçmeyi samimi bulmuyorum. Bana bir etkisi yok. Ancak ödevlerime, derslerime katkı sağlaması, derslerime yardımcı olması bakımından faydası var. Arkadaşlarımdan not istiyorum. Whatsapp'tan yazıyorum. Sende şu not vardır alabilir miyim diye soruyorum ama bu biraz menfaat ilişkisi boyutunda kallyor. Sınıf içi ilişkilerim üzerinde büyük bir etkisi yok.

Ö9: Hayır etkilemiyor. Sosyal medya benim hayatımda var ile yok arasında bir yerde olduğu için hayatıma iyi ya da kötü hiçbir şekilde etki edemiyor. Oynadı̆̆ım oyunların ise sınıf içi ilişkilerime etkisi yok ama benim kendime zararım var bu konuda.

Ö10: Herhangi bir etkisi yok diyebilirim. Sinıfin Whatsapp'ta bir grubu var ama ben o grupta yokum.

Ö12: Mesela bir defasında sosyal medyada çıkan bir tartışma sınıfa kadar taşınmıştı. Problemler olmuştu. Whatsapp'ta ben de bir tartışma yaşadım. O an o kişiyle yan yana olsak boğazlardık belki birbirimizi. Ama Whatsapp'ta olduğu için olay çok büyümedi. Ertesi gün sorunu çözdük. Ama yine de şunu söyleyebilirim sosyal medya kullanımım benim şahsım adına çok olumsuz etki oluşturmuyor. Zaten sosyal medyanın insana yapacă̆ etki yine insanın kendisine bağlı. Kişi, sosyal medyayı nerede nasıl kullanacă̆ını biliyorsa kendisine artı olarak döndürebileceği gibi nasıl kullanacă̆ını bilmiyorsa zararı da olabilir bu tamamen kişinin kendisiyle alakall.

\section{Tartışma ve Sonuç}

Günümüzde bireyler hiçbir sınırlama ile karşı karşıya kalmaksızın bir tuş uzaklığında, sayısını öngörmesinin mümkün olmadığı kitlelere fikirlerini ulaştırmakta ve önemli bir gücü elinde bulundurmaktadır (Tuğlu, 2017). İletişimin hızlı olmasında ve kolay kurulmasında en önemli etkenler, son yıllarda yaşanan teknolojik gelişmeler ve internetin tüm dünyada yaygın olarak kullanılmaya başlanmasıdır. Böylelikle insanlar arasında iletişimin yolları çeşitlenmiştir. Bu yollardan bir tanesi de sosyal medyadır. Sosyal medya, hayatımıza girdiği günden bu yana yüz milyonlarca kullanıcıya ulaşmış ve iletişimin mesafesini kısaltmıştır (Çildan ve diğerleri, 2012). İnsanlar artık sosyal medya aracılığı ile yerinden kalkmadan alışveriş yapabilirken, haberleşebilmekte, eğitim öğretim faaliyetlerini yürütürken, haberleri ve güncel olayları takip edebilmekte ve bilgi alışverişi yapabilmektedirler. Toplumsal hayatın pek çok boyutunda kendine yer edinen sosyal medya, eğitim, öğretim ve iletişim boyutunda da önemli etkiler ortaya çıkarmaktadır.

Örneğin günümüzün en popüler sosyal medya araçlarından olan Facebook ve Twitter ders materyallerini (ses dosyaları, kelime işlemci, tablolama, video dosyaları, sunu, veritabanı ve diğer türde belgeleri içeren web siteleri) 
paylaşmak, gündelik olayları, haberleri, kişileri ve grupları takip etmek, web site adreslerini ve düşünceleri paylaşmak, dil öğrenmek ve iş birliği sağlamak amaçlarıyla eğitim ortamlarında kullanılabilir. Böylelikle aktif, yaratıcı ve iş birlikli bir eğitim öğretim ortamının oluşması ve öğrencilerin derse daha iyi motive olabilmeleri sağlanabilir (Gülbahar ve diğerleri, 2010).

İletişim olanaklarının artmasının etkileri yalnızca eğitim ortamlarında görülmemektedir. Her kesimden bilgi ve iletişim teknolojilerine duyulan ilginin artmasıyla sosyal medyanın gücü artmakta ve sosyalleşme kavramı da yeni bir boyut kazanmaktadır (Akıncı Vural ve Bat, 2010). Öyle ki hiç tanımadığımız bireylerle sosyal medya sayesinde iletişime geçmek, arkadaş olmak, haberleşmek, bilgi paylaşımı yapmak, gerçek hayatta girilmesi mümkün olamayan gruplara üye olmak mümkün olmaktadır (Kakırman Yı1dız, 2012). Böylelikle gerçek hayattan daha farklı olarak sanal hayatta da bir etkileşim ve iletişim ortamı doğmaktadır.

$\mathrm{Bu}$ çalışmada öğrencilere sosyal medya araçları denilince akıllarına ne geldiği, sosyal medya aracı kullanıp kullanmadıkları -kullanıyorlarsa hangilerini kullandıkları-, sosyal medya araçlarına günde ne kadar vakit ayırdıkları, bu araçları hangi amaçlarla kullandıkları, bu araçların bilgiye ulaşabilmeleri, akademik bilgi paylaşımı yapabilmeleri ve sınıf içi etkileşimleri üzerindeki olumlu ve olumsuz etkileri sorulmuştur.

İlk olarak öğrencilere sosyal medya araçları denilince aklınıza neler geliyor? Sorusu yöneltilmiştir. Öğrenciler sosyal medya denilince yoğunluk sırasına göre Facebook, Twitter, Instagram, Whatsapp, Swarm, Snapchat, Youtube ve Tumblr gibi araçların akıllarına geldiğini belirtmişlerdir. Oysaki sosyal medya araçları yalnızca bu araçlardan ibaret değildir. Myspace, Bloglar, Wikiler, Flickr, Xing ve daha pek çok sosyal medya aracı bulunmaktadır (Göker, 2015; Mayfield, 2008, s. 6). Ancak öğrencilerin akıllarına gelen araçlar, görece daha popülerdir. Bu nedenle sosyal medya denilince öğrencilerin akıllarına bu araçların gelmesi olağandır. Bir diğer aşamada öğrencilere sosyal medya araçları kullanıp kullanmadıkları, kullanıyorlarsa hangilerini kullandıkları sorulmuştur. Öğrencilerin tamamının sosyal medya araçlarını kullandıkları saptanmıştır. Bu araçlar Instagram, Youtube, Facebook, Swarm, Online Satranç, Twitter, Messenger ve Whatsapp'tır. Akademik başarısı yüksek olan öğrencilerin daha az sayıda (1-3) akademik başarısı orta ve düşük seviyede olan öğrencilerin daha fazla sayıda (25) sosyal medya aracı kullandıkları belirlenmiştir.

Sosyal medya araçlarına ayrılan sürelere bakıldığında ise akademik başarısı yüksek, orta ve düşük olan öğrenciler arasında belirgin bir farklılığın olduğu ancak akademik başarısı yüksek olan bir öğrencinin sosyal medya kullanımına günde 15 saat, akademik başarısı düşük olan bir öğrencinin de günde 10-15 dakika ayırdığ 1 görülmektedir. Genel tabloya bakıldığında akademik başarı ile sosyal medya kullanımına ayrılan vaktin ters orantılı olduğu görülüyor olsa da önemli olan sosyal medya kullanımına harcanan vaktin nasıl değerlendirildiğidir. Bu nedenle öğrencilere sosyal medya araçlarını hangi amaç veya amaçlarla kullandıkları sorulmuştur. Öğrencilerin sosyal medya araçlarını eğitim, bilgi alışverişi, eğlence, zaman geçirme, arkadaşlarının yapıp ettiklerini kontrol etme, videolar izleme, ders notları derleme ve haberleşme gibi amaçlarla kullandıkları saptanmıştır. Bu anlamda elde edilen bulgular Akıncı Vural ve Bat'ın (2010) bulgularıyla benzerlik göstermektedir.

Alınan cevaplar bilgiye ulaşmak ve akademik bilgi paylaşımı yapabilmek boyutunda değerlendirildiğinde, akademik başarısı yüksek olan öğrencilerin sosyal medyayı daha çok kendilerine akademik olarak katkı sağlaması mümkün olan amaçlarla kullandıkları görülmektedir. Bu öğrenciler, sosyal medyayı kullanma amaçlarından, daha çok ders notlarını derleme, kişisel gelişimlerini destekleme, akademik anlamda kendilerine fayda sağlayabilecek videolar izleme gibi noktalara; akademik başarı düzeyi düşük olan öğrenciler bu amaçlardan farklı noktalara da işaret etmişlerdir. Bu durum bizlere sosyal medyaya ayrılan vaktin, kullanım amacından ayrı düşünülmemesi gerektiğini; bilgiye ulaşma ve akademik bilgi paylaşımı yapabilmenin her ikisinden ortak bir şekilde etkilendiğini göstermektedir.

Sosyal medyanın bilgiye ulaşabilmeleri ve akademik bilgi paylaşımı yapabilmeleri üzerinde olumlu etkiler yaptığını ifade eden öğrenciler, buna pek çok kanıt göstermişlerdir. Bunlar: stresten uzak kalma, motivasyon sağlanması, zihnin rahatlaması, mesleki anlamda bilgi almanın mümkün olması, bilgi kaynaklarına erişimin kolay olması, ders notu paylaşımı, öğretici videolar izlenmesi gibi etkilerdir. Buradan öğrencilerin sosyal medyayı akademik anlamda kendilerine katkı sağlaması için nasıl kullanabileceklerini anladıkları ve buna uygun faaliyetler içerisinde oldukları anlaşılmaktadır. Bu bulgumuz, Tuğlu'nun (2017) çalışmasında elde ettiği, öğrencilerin sosyal medyayı yalnızca iletişim kurma amacıyla değil, bilgiye ulaşmak ve akademik bilgi paylaşımı yapmak amacıyla kullandıkları bulgusu ile örtüşmektedir. Sosyal medyanın bunlar dışında pek çok kullanım amacı olduğu düşünüldüğünde, öğrencilerin kendilerine fayda sağlayabilecek olan seçimler yaptıkları, dolayısıyla bilinçli birer sosyal medya kullanıcıları oldukları belirtilebilir. Bu olumlu örneklere karşılık sosyal medya kullanımının bilgiye 
ulaşabilmelerine ve akademik bilgi paylaşımı yapabilmelerine olumsuz yansıdığını ifade eden öğrenciler de olmuştur. $\mathrm{Bu}$ öğrenciler, sosyal medyada daha fazla zaman geçirme isteğinin, akademik anlamda başlayan konuşmanın boyut değiştirmesinin, ders çalışmaya ara verildiğinde internete ayrılan sürenin uzamasının, sosyal medyaya ayrılan vaktin uzaması nedeniyle akademik çalışmaların ertelenmesinin, ders çalışırken telefona gelen bildirimin dikkat dağıtarak motivasyonu bozmasının bilgiye ulaşmak ve akademik bilgi paylaşımı yapmak üzerinde olumsuz etkiler yaptığını ifade etmişlerdir. Bu anlamda bu bulgumuz Duman'ın (2008) çalışmasından elde ettiği bulgu ile benzerlik göstermektedir. Öğrencilerin ortak şikâyeti sosyal medyaya ayrılan sürenin fazla olmasının ders çalışmaya zaman ayrılmasını zorlaştırdığıdır. Tüm bu etkilere verilen örneklere karşılık sosyal medya kullanımına harcanan vaktin bilgiye ulaşmak ve akademik bilgi paylaşımı yapmak üzerinde hiçbir etkisi olmadığını savunan öğrenciler de bulunmaktadır.

Sosyal medyanın sınıf içi ilişkileri nasıl etkilediği öğrencilere sorulduğunda bu etkinin de olumlu ve olumsuz boyutlarda şekillendiği görülmektedir. Olumlu etkilere gösterilen pek çok kanıt vardır. Bunlar: kişilerle ilgili sahip olunan ön yargıların yıkılması, sosyal medyada başlayan iletişimi sınıfta sürdürmenin daha kolay olması, sosyal medya platformlarında kurulan grupların günlük hayattaki iletişimi daha kolay bir hale getirmesi, sınıf içi kaynaşmanın sağlanması ve yüz yüze iletişim kurmanın zorluğu karşılığında sosyal medya üzerinden iletişim kurmanın kolaylığı şeklindedir. Öğrencilerin sosyal medya kullanmaları sınıf içinde daha etkili bir iletişım ortamının doğmasını sağlamakta ve iletişim sürecini kolaylaştırmaktadır. Bu anlamda sosyal medyanın iletişimi kolaylaştıran rolünün güçlü olduğu ifade edilebilir. Şahin Baltacı, İşleyen ve Özdemir (2012) çalışmalarında sosyal paylaşım ağlarının iletişim kaygısı içinde olan kişiler tarafından tercih edilebilen yerler olduğu vurgulanmaktadır. İlgili çalışmada vurgulanan nokta bulgumuzu destekler niteliktedir. Sosyal medya kullanımının sınıf içi ilişsilere olumsuz yansıdığını belirten öğrenciler ise sosyal medyanın ön yargılı olmaya yol açabildiğini, orada yaşanan tartışmaların sınıf içindeki iletişim ortamına yansıyabildiğini, samimi ilişkilerin sosyal medya yüzünden kurulamadığını, sosyal medyada kurulan samimi ilişkilerin yüz yüze kurulamadığını ifade etmişlerdir. Öğrencilerin bir kısmı ise sosyal medya kullanımlarının sınıf içi ilişkileri üzerinde hiçbir etkisi bulunmadığını ifade etmişlerdir.

Sosyal medya, günümüzde hayatın pek çok alanı üzerinde etkili olmaktadır. Eğitim bu alanların en önemlilerindendir. Bu nedenle sosyal medyanın eğitim-öğretim süreçlerine dahil edilmesi oldukça önemlidir (Özmen, Aküzüm, Sünkür ve Baysal, 2011). Bu anlamda eğitmenlerin ve öğrencilerin sosyal medyanın eğitim potansiyelinin farkında olmaları yadsınamaz bir gerçektir. Yükseköğretim kurumları, sosyal medyanın eğitimöğretim süreçlerinde işe koşulması ile ilgili stratejiler geliştirebilirler ve eğitmenleri süreçte bilgilendirebilirler. $\mathrm{Bu}$ anlamda eğitmenlere hizmet içi eğitimler verilerek bu konudaki farkındalıkların artması ve eğitimle sosyal medya araçlarının bütünleştirilmesi sağlanabilir. Eğitmenler de sosyal medyanın eğitim öğretim sürecinde nasıl kullanılabileceği ile ilgili ögrencilerine seminerler verebilirler. Böylelikle hem eğitmenlerin hem de öğrencilerin sosyal medya hakkında bir bilince erişmeleri sağlanabilir (Kilis, Rapp ve Gülbahar, 2014).

Derslere giren eğitmenler ile öğrencilerin kullandıkları ortak bir sosyal medya grubu oluşturulup bu grupların ders kapsamında kullanılması sağlanabilir. Bu önerimiz Toğay, Akdur, Yetişken ve Bilici'nin (2013) yaptıkları çalışmadaki bulguları ile desteklenmektedir. Bu çalışmada Ankara Meslek Yüksekokulu'nda öğrenim görmekte olan öğrencilerin sosyal medya aracılığı ile eğitim öğretim süreçlerinin desteklenmesini etkili buldukları ortaya konulmuştur. Sosyal medyanın öğretim sürecine dahil edilmesi sayesinde öğrencilerin daha etkin oldukları ve öğrenme süreçlerinin kolaylaştığı da yine bu çalışmada elde edilen bulgulardandır. Eğitimin her kademesinde sosyal ağların kullanılmasına olanak sağlayacak olan teknik alt yapıların okullarda kurulması ve öğretmenlerin bu konuda desteklenmesi yerinde bir yaklaşım olacaktır (Özmen ve diğerleri, 2011).

Sosyal medya artık yediden yetmişe herkesin kullanmakta olduğu bir mecradır. $\mathrm{Bu}$ nedenle okul öncesi seviyesinden üniversite seviyesine kadar sosyal medyanın bilinçli kullanımı ile ilgili derslere yer verilebilir. Medya Okuryazarlığı dersine ayrılan vakit arttırılarak ortaokul seviyesindeki öğrenciler için Medya Okuryazarlı̆̆ dersinin bir ünitesinde, sosyal medya ile ilgili bilgilere ve etkinliklere geniş bir yer ayrılabilir. Ancak bu noktada yalnızca okulun ve öğrencilerin değil ailelerin de sorumluluk almaları sağlanarak okul ve ev arasında bütünleyici, tamamlayıcı ve destekleyici nitelikte bir düzen ortaya konulmalıdır (Elma ve diğerleri, 2009).

Sosyal medyanın kişilerarası ilişkileri etkileyen bir boyutu da vardır. Burada gerek görüntülü gerekse yazılı bir şekilde iletişime geçmeye imkân sağlayan bir ortam bulunmaktadır. Öğrencilerin ifadelerinden yola çıkılarak, sosyal medyadaki iletişim ortamının gerçek hayattaki iletişimi olumlu ve olumsuz boyutlarda etkilediği belirtilebilir. Öğrencilerin, sosyal medyanın iletişim boyutunda yaptığı olumsuz etkilere verdikleri örneklerden en 
dikkat çekeni sosyal medyanın yüz yüze iletişim kurmayı zorlaştırıyor olmasıdır. Çalışma grubunda yer alan öğrencilerin birer öğretmen adayı oldukları ve öğretmenlerin iletişim becerilerinin güçlü olması gerektiği göz önüne alındığında bu konuda öğrencilere yardımcı olunması gerektiği düşünülmektedir. Bu anlamda üniversitelerde verilen İnsan İlişkileri ve İletişim derslerinde öğrencilerin yüz yüze iletişim kurmalarını kolaylaştırmaya yönelik çalışmalara daha fazla yer verilebilir. Öğrencilere sosyal medya kullanırken davranış biçimlerini kontrol altında tutmaları gerektiği ve burada kurulan iletişimin sınıf içindeki etkileşim ortamına yansıyabileceğini düşünerek hareket etmeleri gerektiği belirtilebilir. Akademik çalışmaya ayrılan saatlerin sosyal medya kullanımı ile değerlendirilmesinin çalışma süresini olumsuz etkilediğini belirten öğrenciler olduğundan hareketle, öğrencilerin sosyal medyayı kullanma amaçlarını gözden geçirerek sosyal medyaya ayırdıkları vakti ölçülü tutmalarının yararlı olabileceği düşünülmektedir. $\mathrm{Bu}$ anlamda özellikle ilkokul, ortaokul ve lise seviyesindeki öğrencilerin sosyal medya kullanımına ayırdıkları vaktin aileleri tarafından kontrol altında tutulmasının faydalı olabileceği düşünülmektedir. 


\section{References}

Akbaba, S. (2006). Eğitimde motivasyon. Journal of Kazım Karabekir Education Faculty, 13, 343-361.

Akıncı Vural, Z. \& Bat, M. (2010). Yeni bir iletişim ortamı olarak sosyal medya: Ege Üniversitesi iletişim fakültesine yönelik bir araştırma [Social media as a new communication environment: a research on ege university faculty of communication]. Journal of Yaşar University, 20(5), 3348-3382.

Aziz, A. (2010). Sosyal Bilimlerde araştırma yöntemleri ve teknikleri. Ankara: Nobel Yayın Dağıtım.

Babacan, M. E., Haşlak, İ. \& Hira, İ. (2011). Sosyal medya ve Arap baharı [Arab Spring and the Social Media]. Journal of Academic Inquiries, 6(2), 63-92.

Barutçu, S. \& Tomaş, M. (2013). Sürdürülebilir sosyal medya pazarlaması ve sosyal medya pazarlaması etkinliğinin ölçümü [Sustainable social media marketing and measuring effectiveness of social media marketing]. Journal Of Internet Applications and Management, 4(1), 5-23.

Çildan, C., Ertemiz, M., Küçük E., Tumuçin, H. K. \& Albayrak, D. (2012). Sosyal medyanın politik katılım ve hareketlerdeki rolü [Role of social media in political participation and actions]. Akademik Bilişim 2012 Konferansı 1 - 3 Şubat 2012 Bildirileri İçinde, Uşak Üniversitesi, Uşak, Turkey.

Duman, M. Z. (2008). İnternet kullanımının öğrencilerin sosyal ilişkileri ve okul başarıları üzerindeki etkisi [The effects of internet use on students' social relations and school success]. Toplum ve Demokrasi, 2(3), 93-112.

Ekici, M. \& Kıyıcı, M. (2012). Sosyal ağların eğitim bağlamında kullanımı [Using social networks in educational context]. Usak University Journal of Social Sciences, 5(2), 156-167.

Elma, C., Kesten, A., Dicle, A. N., Mercan E., Çınkır Ş. \& Palavan, Ö.(2009). Medya okuryazarlığı dersinin okul müdürlerinin görüşlerine göre değerlendirilmesi [Evaluation of media literacy course according to school principals' opinions]. Hacettepe University Journal of Education, 36, 87-96.

Göker, G. (2015). İletişimin mcdonaldlaşması: sosyal medya üzerine bir inceleme [Mcdonaldization of communication: an investigation of social media]. Turkish Studies International Periodical For The Languages, Literature and History of Turkish or Turkic, 10(2), 389-410.

Gülbahar, Y., Kalelioğlu, F. \& Madran, O. (2010). Sosyal ağların eğitim amaçlı kullanımı. XV. Türkiye'de Internet Konferansı 2 - 4 Aralık 2010 Bildirileri İçinde, Istanbul Technical University, İstanbul, Turkey.

Hacıefendioğlu, Ş. (2010). Sosyal paylaşım sitelerinde üye bağlılığı üzerine bir araştırma [A research on member loyalty in social networking sites]. Kocaeli Üniversitesi Sosyal Bilimler Enstitüsü Dergisi, 20(2), 5671.

İşlek, M. S. (2012). Sosyal medyanın tüketici davranışlarına etkileri: Türkiye’deki sosyal medya kullanıcıları üzerine bir araştırma [The effects of social media on consumer behaviors: A research on social media users in Turkey]. Graduate Dissertation, Karamanoğlu Mehmetbey University, Karaman, Turkey.

İşman, A. \& Albayrak, E. (2014). Sosyal ağlardan Facebook’un eğitime yönelik etkililiği [Effectiveness of Facebook as a social network in education]. Trakya University Journal of Education, 4(1), 129138.

Kakırman Yıldız, A. (2012). Sosyal paylaşım sitelerinin dijital yerlilerin bilgi edinme ve mahremiyet anlayışına etkisi [The effects of social networking sites on understanding of information and privacy of digital natives]. Information World, 13(2), 529-542.

Kamiloğlu, F. \& Uluğ Yurttaş, Ö. (2014). Sosyal medyanın bilgi edinme ve kişisel gelişim sürecine katkısı ve lise öğrencileri üzerine bir alan çalışması [The contribution of social media on obtaining information and self-improvement, and an fieldwork on high-school students]. Iletişim Dergisi, 21, 129-150.

Kandell, J. J. (1998). Internet addiction on campus: The vulnerability of college students. CyberPsychology \& Behavior, 1(1), 11-17. 
Karagöz, K. (2013). Yeni medya çağında dönüşen toplumsal hareketler ve dijital aktivizm hareketleri. İletişim ve Diplomasi, 1(1), 131-158.

Kilis, S., Rapp, C. \& Gülbahar, Y. (2014). Eğitimde sosyal medya kullanımına yönelik yükseköğretim düzeyindeki eğitmenlerin algısı: Türkiye-Almanya örneklemi [Perception of instructors about social media usage in higher education: The cases of Turkey and Germany]. Journal of Instructional Technologies \& Teacher Education, 3(3), 20-28.

Korkut, F. (2005). Yetişkinlere yönelik iletişim becerileri eğitimi [Communication skills training program for adults]. Hacettepe University Journal of Education, 28, 143-149.

Mayfield, A. (2008). What is social media, iCrossing.

Miles, M. B. \& Huberman, A. M. (2015). Qualitative Data Analysis: An Expanded Sourcebook. Anlamlandırmak, Sonuç Çıkarmak ve Doğrulamak. Trans. Hatice Çiğdem Yıldırım ve Sedat Akayoğlu). S. Akbaba Altun ve A. Ersoy (Eds.) Genişletilmiş Bir Kaynak Kitap Nitel Veri Analizi içinde. Ankara: Pegem Akademi Yayıncılık. (Orijinal çalışmanın yayın tarihi 1994).

Nacar, F. S. \& Tümkaya, S. (2011). Sınıf öğretmenlerinin iletişim ve kişilerarası problem çözme becerilerinin incelenmesi [Analysis of the relationship between the communication of the class teachers and their skills to solve interpersonal problems]. Elementary Education Online, 10(2), 493-511.

Onat, F. \& Aşman Alikılıç, Ö. (2008). Sosyal ağ sitelerinin reklam ve halkla ilişkiler ortamları. Journal of Yaşar University, 3(9), 1111-1143.

Özdemir, M. \& Akar, F. (2011). Lise öğrencilerinin siber-zorbalığa ilişkin görüşlerinin bazı değişkenler bakımından incelenmesi [Examination of high school students' opinions on cyberbullying in terms of various variables]. Educational Administration: Theory and Practice, 17(4), 605-626.

Özmen, F., Aküzüm, C., Sünkür, M. \& Baysal, N. (2011). Sosyal ağ sitelerinin eğitsel ortamlardaki işlevselliği [Functionality of social networks in educational settings]. 6th International Advanced Technologies Symposium (IATS'11) 16- 18 Mayıs 2011 Bildirileri Iç̧inde (pp. 42-47). Fırat University, Elazı̆̆, Turkey.

Öztürk, M. F. ve Talas, M. (2015). Sosyal medya ve eğitim etkileşimi [Interaction of social media and education]. Zeitschrift für die Welt der Türken/Journal of World of Turks, 7(1), 101-120.

Sü Eröz, S. \& Doğdubay, M. (2012). Turistik ürün tercihinde sosyal medyanın rolü ve etik ilişkisi [The role of social media in the choice of tourist products and ethical relationship]. Dokuz Eylul University Faculty of Economics and Administrative Sciences Journal, 27(1), 133-157.

Şahin Baltacı H., İşleyen, F. \& Özdemir, S. (2012). Eğitim fakültesi öğrencilerinin romantik ilişki durumları ve sosyal ağ kullanımlarına göre etkileşim kaygısı ve sosyal destek algılarının incelenmesi [The investigation of interaction anxiety and social support perceptions of the faculty of education students according to the romantic relationship status and social network use]. Mersin University Journal of the Faculty of Education, 8(2), 25-36.

Toğay, A., Akdur, T. E. , Yetişken, İ. C. \& Bilici, A. (2013). Eğitim süreçlerinde sosyal ağların kullanımı: Bir MYO deneyimi [The usage of social networks in education processes: a vocational high school experience]. Akademik Bilişim Konferansı Bildirileri II. Cilt 23 - 25 Ocak 2013 (pp. 1006-1011). Akdeniz University, Antalya, Turkey.

Toksarı, M., Mürütsoy, M. \& Bayraktar, M. (2014). Tüketici algılarını etkileyen faktörlerde sosyal medyanın rolü: Niğde Üniversitesi İ.İ.B.F. örneği [The Role of Social Media in Factors Affecting Consumer Perception: Nigde University I.I.B.F. Instance]. Usak University Journal of Social Sciences, 7(4), 128.

Tuğlu, B. (2017). Ortaokul ögrencilerinin sosyal medyayı kullanım amaçları ve sosyal medya kullanımlarına ilişkin tutumlarl [The aims of social media use of secondary school students' and attitudes towards social media use]. Graduate Dissertation, Sakarya University, Sakarya, Turkey. 
Yağmurlu, A. (2011). Kamu yönetiminde halkla ilişkiler ve sosyal medya [Public relations and social media practices in public administration]. Journal of Selcuk Communication, 7(1), 5-15.

Yegen, C. (2013). Demokratik ve yeni bir kamusal alan olarak sosyal medya [Social media as democratic and a new public area]. Journal of Social Sciences of Mus Alparslan University, 1(2), 119-135.

Yıldırım, A. ve Şimşek, H. (2013). Sosyal Bilimlerde Nitel Araştırma Yöntemleri. (9. genişletilmiş baskı). Ankara: Seçkin Yayıncılık.

Young, K. S. (1998). Internet addiction: The emergence of a new clinical disorder. Cyberpsychology and Behavior, 1(3), 237-244.

Yüksel Şahin, F. (1998). Grupla iletişim becerileri eğitiminin üniversite öğrencilerinin iletişim beceri düzeylerine etkisi [Effect of communication skills training within a group upon communication skill levels of university students]. Education and Science, 22(110), 12-19. 